\title{
Macrofungi as a Nutraceutical Source: Promising Bioactive Compounds and Market Value
}

\author{
Allen Grace Niego ${ }^{1,2,3}$, Sylvie Rapior ${ }^{4}$, Naritsada Thongklang ${ }^{1,2} \mathbb{1}$, Olivier Raspé ${ }^{1,2}$, Wuttichai Jaidee ${ }^{5}$, \\ Saisamorn Lumyong ${ }^{6,7,8}\left(\mathbb{D}\right.$ and Kevin D. Hyde ${ }^{1,6,9, *}$
}

1 Center of Excellence in Fungal Research, Mae Fah Luang University, Chiang Rai 57100, Thailand; agniego27@gmail.com (A.G.N.); naritsada.t@gmail.com (N.T.); ojmraspe@gmail.com (O.R.)

2 School of Science, Mae Fah Luang University, Chiang Rai 57100, Thailand

3 Iloilo Science and Technology University, La Paz, Iloilo 5000, Philippines

4 Laboratory of Botany, Phytochemistry and Mycology, Faculty of Pharmacy, CEFE, CNRS, University Montpellier, EPHE, IRD, CS 14491, 15 Avenue Charles Flahault, CEDEX 5, 34093 Montpellier, France; sylvie.rapior@umontpellier.fr

5 Medicinal Plants Innovation Center, Mae Fah Luang University, Chiang Rai 57100, Thailand; wuttichai.jai@mfu.ac.th

6 Department of Biology, Faculty of Science, Chiang Mai University, Chiang Mai 50200, Thailand; scboi009@gmail.com

7 Research Center of Microbial Diversity and Sustainable Utilization, Chiang Mai University, Chiang Mai 50200, Thailand

8 Academy of Science, The Royal Society of Thailand, Bangkok 10300, Thailand

9 Innovative Institute of Plant Health, Zhongkai University of Agriculture and Engineering, Guangzhou 510408, China

check for updates

Citation: Niego, A.G.; Rapior, S.; Thongklang, N.; Raspé, O.; Jaidee, W.; Lumyong, S.; Hyde, K.D. Macrofungi as a Nutraceutical Source: Promising Bioactive Compounds and Market Value. J. Fungi 2021, 7, 397. https:/ / doi.org/10.3390/jof7050397

Academic Editors:

Jasmina Glamočlija and

Dejan Stojković

Received: 29 April 2021

Accepted: 16 May 2021

Published: 19 May 2021

Publisher's Note: MDPI stays neutral with regard to jurisdictional claims in published maps and institutional affiliations.
* Correspondence: kdhyde3@gmail.com

\begin{abstract}
Macrofungi production and economic value have been increasing globally. The demand for macrofungi has expanded rapidly owing to their popularity among consumers, pleasant taste, and unique flavors. The presence of high quality proteins, polysaccharides, unsaturated fatty acids, minerals, triterpene sterols, and secondary metabolites makes macrofungi an important commodity. Macrofungi are well known for their ability to protect from or cure various health problems, such as immunodeficiency, cancer, inflammation, hypertension, hyperlipidemia, hypercholesterolemia, and obesity. Many studies have demonstrated their medicinal properties, supported by both in vivo and in vitro experimental studies, as well as clinical trials. Numerous bioactive compounds isolated from mushrooms, such as polysaccharides, proteins, fats, phenolic compounds, and vitamins, possess strong bioactivities. Consequently, they can be considered as an important source of nutraceuticals. Numerous edible mushrooms have been studied for their bioactivities, but only a few species have made it to the market. Many species remain to be explored. The converging trends and popularity of eastern herbal medicines, natural/organic food product preference, gut-healthy products, and positive outlook towards sports nutrition are supporting the growth in the medicinal mushroom market. The consumption of medicinal mushrooms as functional food or dietary supplement is expected to markedly increase in the future. The global medicinal mushroom market size is projected to increase by USD 13.88 billion from 2018 to 2022. The global market values of promising bioactive compounds, such as lentinan and lovastatin, are also expected to rise. With such a market growth, mushroom nutraceuticals hold to be very promising in the years to come.
\end{abstract}

Keywords: bioactivities; macrofungi; medicinal properties; market value; nutraceuticals; nutrients

\section{Introduction}

Macrofungi (from the Greek "makros", meaning large), includes members of the phylum Basidiomycota, and a few Ascomycota that fruit above or below the ground, with large sporocarps or fruiting bodies that can be seen with the unaided eye [1]. Macrofungi, 
collectively referred to as mushrooms, are distributed throughout the world, with about 14,000 species globally [2]. About 350 species of mushrooms are consumed around the world [3]. The most cultivated edible mushrooms worldwide are Agaricus bisporus (button mushroom), Flammulina velutipes (enoki mushroom), Lentinula edodes (shiitake mushroom), and Pleurotus spp., in particular oyster mushroom [4-7]. In the last decade, China has made some significant breakthroughs in the breeding and cultivation techniques of edible mushrooms, as well as product innovations, which has led to increased mushroom production [8]. Many people consume mushrooms because of health-promoting benefits [9], a driving force in the increased market value of medicinal mushrooms [10]. At least 270 species of macrofungi have been explored as sources of important secondary metabolites and have the potential to be developed as food supplements for medicinal applications [11].

Macrofungi production and economic value have increased globally [2]. Because of the increasing mushroom demand, it is expected that the total value of the global mushroom market per annum will exceed USD 50 billion in the coming few years [12]. The global market value of edible mushrooms is forecasted to reach up to USD 62.19 billion in 2023 [13]. The popularity of macrofungi among consumers has expanded, owing to their pleasant and unique flavors, as well as for their health benefits [14]. Since the 20th century, the demand for food has increased and the requirements for consumables have become more stringent [15]. Food should not only provide nourishment and satisfy hunger, but should also aid in the improvement of the physical and psychological condition of humans and especially aid in preventing and treating diseases [16]. Many bioactivities of macrofungi, such as anticancer, antidiabetics, antihypertensive, antimicrobial, anti-inflammatory, antioxidant, immunomodulatory, cholesterol lowering, neurotrophic, and neuroprotective properties, have been well studied [17-20]. Macrofungi, both wild and cultivated, can be seen as healthy functional food [17]. The fresh fruiting bodies of macrofungi have a moisture content of approximately $70-95 \%$. The dry matter is composed of carbohydrates $(50-65 \%)$, proteins $(19-35 \%)$, and essential fatty acids $(2-6 \%)$, with traces of vitamins and minerals [21]. Edible mushrooms could be a source of many different nutraceuticals, such as $\beta$-glucans, lectins, unsaturated fatty acids, phenolic compounds, tocopherols, ascorbic acid, and carotenoids. Thus, consumption of edible macrofungi promotes health, taking advantage of the additive and synergistic effects of all the bioactive compounds present [22]. Hence, macrofungi are potentially important sources of low-calorie functional foods and nutraceuticals [2].

The most widely cultivated edible macrofungi are A. bisporus (button macrofungi), Auricularia auricula (wood ear macrofungi), F. velutipes (winter macrofungi), L. edodes (shiitake), Pleurotus spp. (oyster macrofungi), and Volvariella volvacea [23,24]. Moreover, macrofungi such as Ganoderma lingzhi-G. sichuanense (Lingzhi or Reishi), Inonotus obliquus (Chaga), L. edodes (Shiitake), and many others have been collected in the wild and utilized as medicines for hundreds of years in many Asian countries, such as Korea, China, Japan, and eastern Russia. Such practices have prompted modern scientific studies of fungal medicinal properties, especially anticancer bioactivities [25]. The most explored species for their medicinal value are Antrodia cinnamomea, Ganoderma lingzhi-G. sichuanense, Ophiocordyceps sinensis, Phellinus linteus, and Xylaria nigripes $[17,26,27]$. Numerous bioactive compounds have been found in their fruiting bodies or cultured mycelium, such as alkaloids, carotenoids, enzymes, fats, folates, glycosides, lectins, minerals, organic acids, phenolics, polysaccharides, proteins, terpenoids, tocopherols, and volatile compounds in general $[5,28,29]$. The fruiting bodies of macrofungi have approximately $70-95 \%$ moisture content, with abundant carbohydrates (50-65\%), proteins (19-35\%), and some fats (2-6\%) [21], in which many are bioactive constituents, such as polysaccharides, biologically active proteins (enzymes, lectins, and ergothioneine), unsaturated fatty acids (oleic and linoleic), phenolic compounds (phenolic acids and polyphenols), vitamins (A, B complex, C), and dietary fibers $[26,30]$. 
This review aims to establish the potential of mushrooms as nutraceuticals, with emphasis on their medicinal properties and bioactive compounds. Experimental in vivo and in vitro studies, and clinical trials supporting the bioactivities of the different compounds from edible mushrooms are compiled. The market value of medicinal mushrooms and bioactive compounds from market studies is also established in this review. Macrofungal resources have not been fully explored yet, thus a lot of studies are still needed to unlock their diverse potential applications [2].

\section{Nutritional Value of Mushrooms}

The moisture content of fresh mushrooms varies from 70 to $95 \%$, depending on the environmental conditions and time of harvest. Mushrooms are known to be rich in high quality protein, and to contain a high proportion of unsaturated fatty acids as a form of vegetable. Mushrooms are also a good source of fiber, particularly the soluble fiber $\beta$-glucan [31]. The fruiting bodies of mushrooms are made up of 50 to $60 \%$ of carbohydrates on a dry weight basis, with free sugars amounting to $11 \%$ [32]. The carbohydrate content of Pleurotus ostreatus (white strain) was reported to be 56\% [33]. The most dominant mushroom sugar is mannitol which constitutes about $80 \%$ of the total free sugars [34]. Proteins are an important functional component of mushroom fruiting bodies. Mushrooms, in general, have a higher protein content than most other vegetables and most wild plants. Based on the data published by the USDA in 2019, $100 \mathrm{~g}$ of raw mushrooms contains only $22 \mathrm{kcal}$. Overall, nutrients are present as follows: carbohydrates (3.26 g/100 g DW), protein (3.09 g/100 g DW), fiber (1.0 g/100 g DW), and fat (0.34 g/100 g DW). Mushrooms have a low glycemic index and are presumed to have little negative effect on blood glucose and insulin response [35]. Mushrooms are also full of micronutrients, such as the vitamin B complex, including vitamin B5, which assists in the release of energy from carbohydrates, proteins, and fat [29]. Mushrooms also contain a high level of mineral elements that are essential for human health. Major mineral constituents in mushrooms are $\mathrm{K}, \mathrm{P}, \mathrm{Na}, \mathrm{Ca}$, and $\mathrm{Mg}$, as well as minor elements, including $\mathrm{Cu}, \mathrm{Zn}, \mathrm{Fe}, \mathrm{Mo}$, and $\mathrm{Cd}$ [36]. The content in minerals depends mostly on the substrates supplied for mushroom cultivation, as well as the species, age, and size of the fruiting bodies. Wild mushrooms tend to have higher mineral contents compared to cultivated ones [37]. Table 1 lists some edible mushrooms and their moisture, protein, ash, fat, and carbohydrate contents.

Table 1. Nutrient content of some economically important and other selected mushroom species.

\begin{tabular}{|c|c|c|c|c|c|c|}
\hline Species & $\begin{array}{l}\text { Moisture } \\
\text { (g/100 g FW or } \\
\text { DW) }\end{array}$ & $\begin{array}{l}\text { Ash } \\
\text { (g/100 g DW) }\end{array}$ & $\begin{array}{l}\text { Proteins } \\
\text { (g/100 g DW) }\end{array}$ & $\begin{array}{l}\text { Fat } \\
\text { (g/100 g DW) }\end{array}$ & $\begin{array}{l}\text { Carbohydrates } \\
\text { (g/100 g DW) }\end{array}$ & References \\
\hline Agaricus bisporus & $\begin{array}{l}90.09 \pm 0.07 \\
(\mathrm{FW})\end{array}$ & $9.17 \pm 0.52$ & $24.43 \pm 0.10$ & $3.06 \pm 0.03$ & $53.10 \pm 0.56$ & [38] \\
\hline Agaricus brasiliensis & $6.5 \pm 0.11(\mathrm{DW})$ & $8.9 \pm 0.09$ & $37.3 \pm 0.22$ & $92.4 \pm 0.03$ & $44.9 \pm 2.5$ & [39] \\
\hline Agaricus campestris & $\begin{array}{l}88.17 \pm 0.44 \\
(\mathrm{FW})\end{array}$ & $23.16 \pm 0.00$ & $18.57 \pm 0.00$ & $0.11 \pm 0.00$ & $58.16 \pm 0.00$ & {$[40]$} \\
\hline Agaricus comtulus & $\begin{array}{l}87.94 \pm 0.77 \\
(\mathrm{FW})\end{array}$ & $28.14 \pm 0.18$ & $21.29 \pm 0.83$ & $0.46 \pm 0.00$ & $50.11 \pm 0.89$ & [40] \\
\hline $\begin{array}{l}\text { Amanita battarrae (as } \\
\text { A. umbrinolutea) }\end{array}$ & $\begin{array}{l}73.60 \pm 0.17 \\
(\mathrm{FW})\end{array}$ & $28.86 \pm 0.00$ & $16.78 \pm 0.00$ & $6.77 \pm 0.00$ & $47.59 \pm 0.00$ & [40] \\
\hline Amanita caesarea & - & $6.05 \pm 0.01$ & $34.77 \pm 0.06$ & $3.50 \pm 0.00$ & $55.63 \pm 0.06$ & [41] \\
\hline Armillaria mellea & $\begin{array}{l}88.27 \pm 0.60 \\
(\mathrm{FW})\end{array}$ & $6.78 \pm 1.28$ & $16.38 \pm 1.34$ & $5.56 \pm 0.53$ & $71.28 \pm 1.06$ & [42] \\
\hline Armillaria mellea & - & $7.95 \pm 0.02$ & $24.47 \pm 0.12$ & $2.10 \pm 0.02$ & $65.47 \pm 0.15$ & [41] \\
\hline Armillaria tabescens & - & $7.63 \pm 0.15$ & $22.90 \pm 0.20$ & $2.54 \pm 0.03$ & $66.87 \pm 0.06$ & [41] \\
\hline
\end{tabular}


Table 1. Cont.

\begin{tabular}{|c|c|c|c|c|c|c|}
\hline Species & $\begin{array}{l}\text { Moisture } \\
\text { (g/100 g FW or } \\
\text { DW) }\end{array}$ & $\begin{array}{l}\text { Ash } \\
\text { (g/100 g DW) }\end{array}$ & $\begin{array}{l}\text { Proteins } \\
\text { (g/100 g DW) }\end{array}$ & $\begin{array}{l}\text { Fat } \\
\text { (g/100 g DW) }\end{array}$ & $\begin{array}{l}\text { Carbohydrates } \\
\text { (g/100 g DW) }\end{array}$ & References \\
\hline $\begin{array}{l}\text { Auricularia } \\
\text { auricula-judae }\end{array}$ & $\begin{array}{l}88.9 \pm 0.02 \\
(\mathrm{FW})\end{array}$ & $3.15 \pm 0.3$ & $56.92 \pm 0.01$ & - & $18.67 \pm 0.01$ & {$[43]$} \\
\hline $\begin{array}{l}\text { Auricularia nigricans } \\
\text { (as A. polytricha) }\end{array}$ & $\begin{array}{l}82.01 \pm 0.04 \\
(\mathrm{FW})\end{array}$ & $8.44 \pm 0.8$ & $42 \pm 0.02$ & - & $16.03 \pm 0.02$ & {$[43]$} \\
\hline Auricularia thailandica & $\begin{array}{l}80.75 \pm 0.20 \\
(\mathrm{FW})\end{array}$ & $4.30 \pm 0.02$ & $12.99 \pm 0.05$ & $2.93 \pm 0.66$ & - & {$[44]$} \\
\hline Boletus aereus & $\begin{array}{l}91.65 \pm 1.04 \\
(\mathrm{FW})\end{array}$ & $8.87 \pm 0.10$ & $17.86 \pm 0.96$ & $0.44 \pm 0.08$ & $72.83 \pm 0.90$ & {$[45]$} \\
\hline Boletus aureus & - & $6.25 \pm 0.02$ & $27.17 \pm 0.15$ & $4.47 \pm 0.02$ & $62.10 \pm 0.10$ & [41] \\
\hline Boletus edulis & $\begin{array}{l}89.15 \pm 0.90 \\
(\mathrm{FW})\end{array}$ & $5.53 \pm 0.23$ & $21.07 \pm 0.66$ & $2.45 \pm 0.09$ & $70.96 \pm 0.66$ & {$[45]$} \\
\hline Boletus fragrans & $\begin{array}{l}77.99 \pm 0.07 \\
(\mathrm{FW})\end{array}$ & $4.74 \pm 0.19$ & $17.15 \pm 0.04$ & $1.83 \pm 0.17$ & $76.29 \pm 0.27$ & [46] \\
\hline Boletus reticulatus & $\begin{array}{l}91.10 \pm 2.21 \\
(\mathrm{FW})\end{array}$ & $19.72 \pm 0.25$ & $22.57 \pm 2.08$ & $2.55 \pm 0.01$ & $55.16 \pm 2.03$ & [45] \\
\hline Bovista aestivalis & $\begin{array}{l}73.23 \pm 0.93 \\
(\mathrm{FW})\end{array}$ & $31.86 \pm 0.20$ & $15.59 \pm 1.23$ & $0.18 \pm 0.02$ & $52.37 \pm 1.31$ & {$[40]$} \\
\hline Bovista nigrescens & $\begin{array}{l}76.41 \pm 0.18 \\
(\mathrm{FW})\end{array}$ & $3.24 \pm 0.17$ & $20.94 \pm 0.31$ & $3.64 \pm 0.96$ & $72.18 \pm 0.76$ & [40] \\
\hline $\begin{array}{l}\text { Bovistella utriformis } \\
\text { (as Calvatia utriformis) }\end{array}$ & $\begin{array}{l}78.00 \pm 1.36 \\
(\mathrm{FW})\end{array}$ & $17.81 \pm 0.22$ & $20.37 \pm 0.49$ & $1.90 \pm 0.01$ & $59.91 \pm 0.40$ & [46] \\
\hline Calocybe gambosa & $\begin{array}{l}90.92 \pm 1.08 \\
(\mathrm{FW})\end{array}$ & $13.89 \pm 1.41$ & $15.46 \pm 0.24$ & $0.83 \pm 0.11$ & $69.83 \pm 1.22$ & [42] \\
\hline Cantharellus cibarius & - & $9.44 \pm 0.01$ & $21.57 \pm 0.21$ & $2.88 \pm 0.02$ & $66.07 \pm 0.23$ & [41] \\
\hline $\begin{array}{l}\text { Chlorophyllum } \\
\text { rhacodes }\end{array}$ & $\begin{array}{l}88.28 \pm 0.33 \\
(\mathrm{FW})\end{array}$ & $12.10 \pm 0.31$ & $19.32 \pm 0.04$ & $3.29 \pm 0.33$ & $65.29 \pm 0.48$ & [40] \\
\hline $\begin{array}{l}\text { Clavariadelphus } \\
\text { pistillaris }\end{array}$ & $\begin{array}{l}84.22 \pm 1.78 \\
(\mathrm{FW})\end{array}$ & $20.77 \pm 0.86$ & $16.27 \pm 0.24$ & $0.59 \pm 0.07$ & $62.37 \pm 0.48$ & [40] \\
\hline $\begin{array}{l}\text { Clavariadelphus } \\
\text { truncatus }\end{array}$ & $\begin{array}{l}90.97 \pm 1.29 \\
(\mathrm{FW})\end{array}$ & $12.86 \pm 0.33$ & $15.98 \pm 0.15$ & $1.54 \pm 0.25$ & $69.62 \pm 0.37$ & [40] \\
\hline Clitocybe costata & $\begin{array}{l}76.92 \pm 2.11 \\
(\mathrm{FW})\end{array}$ & $10.87 \pm 1.36$ & $17.27 \pm 0.25$ & $1.50 \pm 0.00$ & $70.36 \pm 1.10$ & {$[40]$} \\
\hline Clitocybe odora & $\begin{array}{l}88.49 \pm 3.03 \\
(\mathrm{FW})\end{array}$ & $9.55 \pm 0.68$ & $17.33 \pm 1.37$ & $2.46 \pm 0.04$ & $70.66 \pm 1.09$ & [42] \\
\hline Clitopilus prunulus & $\begin{array}{l}89.78 \pm 1.46 \\
(\mathrm{FW})\end{array}$ & $30.19 \pm 2.50$ & $18.13 \pm 0.37$ & $1.01 \pm 0.06$ & $50.66 \pm 2.21$ & [46] \\
\hline Coprinus comatus & $\begin{array}{l}85.19 \pm 0.50 \\
(\mathrm{FW})\end{array}$ & $12.85 \pm 0.42$ & $15.67 \pm 0.23$ & $1.13 \pm 0.05$ & $70.36 \pm 0.26$ & [42] \\
\hline Coprinus comatus & $4.2 \pm 0.06(\mathrm{DW})$ & $13.2 \pm 0.42$ & $22.7 \pm 0.37$ & $1.3 \pm 0.02$ & $58.6 \pm 5.1$ & [39] \\
\hline Cordyceps militaris & $7.7 \pm 0.61(\mathrm{DW})$ & $5.4 \pm 0.16$ & $29.7 \pm 0.42$ & $2.9 \pm 0.18$ & $54.3 \pm 5.5$ & [39] \\
\hline Fistulina hepatica & - & $8.2 \pm 0.10$ & $22.6 \pm 0.20$ & $3.17 \pm 0.02$ & $66.0 \pm 0.10$ & [41] \\
\hline Flammulina velutipes & $5.0 \pm 0.13(\mathrm{DW})$ & $8.3 \pm 0.08$ & $23.4 \pm 0.19$ & $2.1 \pm 0.10$ & $61.2 \pm 4.3$ & [39] \\
\hline $\begin{array}{l}\text { Ganoderma lingzhi/G. } \\
\text { sichuanense (as } \\
\text { Ganoderma lucidum) }\end{array}$ & $5.1 \pm 0.16(\mathrm{DW})$ & $1.0 \pm 0.00$ & $9.2 \pm 0.32$ & $1.1 \pm 0.01$ & $83.6 \pm 4.4$ & [39] \\
\hline Grifola frondosa & $4.8 \pm 0.08(\mathrm{DW})$ & $4.7 \pm 0.07$ & $18.3 \pm 0.34$ & $5.3 \pm 0.09$ & $66.9 \pm 8.4$ & [39] \\
\hline $\begin{array}{l}\text { Hemileccinum } \\
\text { impolitum (as Boletus } \\
\text { impolitus) }\end{array}$ & $\begin{array}{l}88.90 \pm 1.45 \\
(\mathrm{FW})\end{array}$ & $24.43 \pm 0.84$ & $16.01 \pm 0.02$ & $2.94 \pm 0.33$ & $56.63 \pm 0.84$ & [40] \\
\hline Hericium erinaceus & $6.2 \pm 0.14(\mathrm{DW})$ & $6.8 \pm 0.22$ & $20.8 \pm 0.43$ & $5.1 \pm 0.11$ & $61.1 \pm 3.6$ & [39] \\
\hline $\begin{array}{l}\text { Hortiboletus engelii (as } \\
\text { Boletus armeniacus) }\end{array}$ & $\begin{array}{l}71.50 \pm 0.43 \\
(\mathrm{FW})\end{array}$ & $12.09 \pm 0.35$ & $18.25 \pm 0.06$ & $1.56 \pm 0.42$ & $68.10 \pm 0.51$ & [40] \\
\hline $\begin{array}{l}\text { Hygrophorus } \\
\text { chrysodon }\end{array}$ & $\begin{array}{l}92.09 \pm 1.01 \\
(\mathrm{FW})\end{array}$ & $26.91 \pm 1.99$ & $15.11 \pm 0.18$ & $3.48 \pm 0.09$ & $54.51 \pm 1.28$ & [40] \\
\hline
\end{tabular}


Table 1. Cont.

\begin{tabular}{|c|c|c|c|c|c|c|}
\hline Species & $\begin{array}{l}\text { Moisture } \\
\text { (g/100 g FW or } \\
\text { DW) }\end{array}$ & $\begin{array}{l}\text { Ash } \\
\text { (g/100 g DW) }\end{array}$ & $\begin{array}{l}\text { Proteins } \\
\text { (g/100 g DW) }\end{array}$ & $\begin{array}{l}\text { Fat } \\
\text { (g/100 g DW) }\end{array}$ & $\begin{array}{l}\text { Carbohydrates } \\
\text { (g/100 g DW) }\end{array}$ & References \\
\hline $\begin{array}{l}\text { Hygrophorus } \\
\text { pustulatus }\end{array}$ & $\begin{array}{l}93.03 \pm 0.79 \\
(\mathrm{FW})\end{array}$ & $14.04 \pm 0.14$ & $18.64 \pm 0.40$ & $3.06 \pm 0.51$ & $64.26 \pm 0.72$ & [46] \\
\hline Hygrophorus russula & - & $8.18 \pm 0.02$ & $32.47 \pm 0.06$ & $6.00 \pm 0.10$ & $53.33 \pm 0.06$ & {$[41]$} \\
\hline $\begin{array}{l}\text { Infundibulicybe gibba } \\
\text { (as Clitocybe gibba) }\end{array}$ & $\begin{array}{l}72.66 \pm 0.99 \\
(\mathrm{FW})\end{array}$ & $20.68 \pm 0.15$ & $14.59 \pm 0.27$ & $4.29 \pm 0.00$ & $60.45 \pm 0.23$ & {$[40]$} \\
\hline Lactifluus piperatus & $\begin{array}{l}80.03 \pm 0.02 \\
(\mathrm{FW})\end{array}$ & $5.38 \pm 0.6$ & $19.33 \pm 0.02$ & - & $9.2 \pm 0.07$ & {$[43]$} \\
\hline Laetiporus sulphureus & $\begin{array}{l}49.8 \pm 0.02 \\
(\mathrm{FW})\end{array}$ & $4.81 \pm 0.5$ & $22.73 \pm 0.01$ & - & $7.65 \pm 0.01$ & [43] \\
\hline Lentinula edodes & $7.3 \pm 0.10(\mathrm{DW})$ & $5.1 \pm 0.05$ & $18.5 \pm 0.16$ & $0.8 \pm 0.01$ & $68.3 \pm 4.7$ & [39] \\
\hline Lentinula edodes & $\begin{array}{l}82.8 \pm 0.01 \\
(\mathrm{FW})\end{array}$ & $5.59 \pm 0.3$ & $43.81 \pm 0.02$ & - & $38.44 \pm 0.01$ & [43] \\
\hline Lentinus sajor-caju & $\begin{array}{l}85.1 \pm 0.02 \\
(\mathrm{FW})\end{array}$ & $8.41 \pm 0.2$ & $62.27 \pm 0.02$ & - & $6.81 \pm 0.01$ & {$[43]$} \\
\hline $\begin{array}{l}\text { Lentinus sajor-caju (as } \\
\text { Pleurotus sajor-caju) }\end{array}$ & $\begin{array}{l}89.58 \pm 0.19 \\
(\mathrm{FW})\end{array}$ & $7.46 \pm 0.30$ & $25.65 \pm 0.05$ & $1.96 \pm 0.12$ & $52.46 \pm 0.43$ & [38] \\
\hline Lentinus squarrosulus & $\begin{array}{l}87.3 \pm 0.02 \\
(\mathrm{FW})\end{array}$ & $10.66 \pm 0.4$ & $27.86 \pm 0.01$ & - & $9.32 \pm 0.01$ & [43] \\
\hline $\begin{array}{l}\text { Lentinus squarrosulus } \\
\text { var. squarrosulus }\end{array}$ & $\begin{array}{l}86.2 \pm 0.01 \\
(\mathrm{FW})\end{array}$ & $3.12 \pm 0.2$ & $18.77 \pm 0.02$ & - & $19.14 \pm 0.01$ & [43] \\
\hline Lentinus tigrinus & $\begin{array}{l}73.7 \pm 0.04 \\
(\mathrm{FW})\end{array}$ & $3.41 \pm 0.2$ & $31.85 \pm 0.03$ & - & $16.09 \pm 0.3$ & [43] \\
\hline Lepista nuda & - & $6.03 \pm 0.02$ & $34.37 \pm 0.15$ & $3.23 \pm 0.01$ & $56.33 \pm 0.15$ & [41] \\
\hline $\begin{array}{l}\text { Leucoagaricus } \\
\text { leucothites }\end{array}$ & $\begin{array}{l}85.29 \pm 1.00 \\
(\mathrm{FW})\end{array}$ & $26.46 \pm 0.01$ & $20.51 \pm 0.47$ & $1.10 \pm 0.15$ & $51.93 \pm 0.53$ & {$[40]$} \\
\hline Lycoperdon echinatum & $\begin{array}{l}85.24 \pm 0.48 \\
(\mathrm{FW})\end{array}$ & $9.43 \pm 0.23$ & $23.52 \pm 2.20$ & $1.22 \pm 0.20$ & $65.83 \pm 2.09$ & [46] \\
\hline Lycoperdon umbrinum & $\begin{array}{l}71.98 \pm 0.32 \\
(\mathrm{FW})\end{array}$ & $33.14 \pm 1.06$ & $14.53 \pm 0.07$ & $0.37 \pm 0.00$ & $51.96 \pm 0.70$ & {$[40]$} \\
\hline Lyophyllum decastes & $\begin{array}{l}87.38 \pm 1.40 \\
(\mathrm{FW})\end{array}$ & $7.38 \pm 0.64$ & $25.52 \pm 3.49$ & $2.10 \pm 0.12$ & $64.99 \pm 2.96$ & {$[46]$} \\
\hline Macrolepiota excoriata & $\begin{array}{l}88.92 \pm 1.57 \\
(\mathrm{FW})\end{array}$ & $28.98 \pm 1.11$ & $25.28 \pm 2.64$ & $1.55 \pm 0.10$ & $44.19 \pm 2.14$ & [46] \\
\hline $\begin{array}{l}\text { Morchella esculenta (as } \\
\text { Morchella conica) }\end{array}$ & - & $14.6 \pm 0.30$ & $7.5 \pm 0.40$ & $2.8 \pm 0.10$ & $75.0 \pm 0.40$ & [47] \\
\hline $\begin{array}{l}\text { Neoboletus erythropus } \\
\text { (as Boletus erythropus) }\end{array}$ & $\begin{array}{l}88.36 \pm 1.49 \\
(\mathrm{FW})\end{array}$ & $25.90 \pm 0.28$ & $20.92 \pm 0.05$ & $0.75 \pm 0.02$ & $52.44 \pm 0.20$ & {$[46]$} \\
\hline Pleurotus ostreatus & $8.2 \pm 0.07(\mathrm{DW})$ & $7.1 \pm 0.06$ & $33.5 \pm 0.22$ & $2.3 \pm 0.07$ & $48.9 \pm 2.7$ & {$[39]$} \\
\hline Ramaria aurea & $\begin{array}{l}88.52 \pm 0.12 \\
(\mathrm{FW})\end{array}$ & $5.68 \pm 0.74$ & $14.60 \pm 0.10$ & $2.26 \pm 0.05$ & $77.47 \pm 0.61$ & {$[40]$} \\
\hline Ramaria largentii & - & $6.67 \pm 0.12$ & $28.80 \pm 0.46$ & $5.67 \pm 0.12$ & $58.87 \pm 0.25$ & [41] \\
\hline Russula cyanoxantha & $\begin{array}{l}85.44 \pm 0.99 \\
(\mathrm{FW})\end{array}$ & $7.03 \pm 0.87$ & $16.80 \pm 0.06$ & $1.52 \pm 0.52$ & $74.65 \pm 1.01$ & [46] \\
\hline Russula delica & - & $5.61 \pm 0.03$ & $26.10 \pm 0.30$ & $4.44 \pm 0.04$ & $63.87 \pm 0.31$ & [41] \\
\hline Russula olivacea & $\begin{array}{l}84.58 \pm 1.01 \\
(\mathrm{FW})\end{array}$ & $37.78 \pm 5.20$ & $16.84 \pm 0.05$ & $1.99 \pm 0.44$ & $43.38 \pm 3.71$ & {$[46]$} \\
\hline $\begin{array}{l}\text { Schizophyllum } \\
\text { commune }\end{array}$ & $\begin{array}{l}69.8 \pm 0.02 \\
(\mathrm{FW})\end{array}$ & $6.02 \pm 0.6$ & $24.42 \pm 0.02$ & - & $5.31 \pm 0.01$ & [43] \\
\hline Suillus variegatus & $\begin{array}{l}90.77 \pm 0.76 \\
(\mathrm{FW})\end{array}$ & $15.36 \pm 2.10$ & $17.57 \pm 0.56$ & $3.31 \pm 0.49$ & $63.76 \pm 2.17$ & {$[40]$} \\
\hline Termitomyces heimii & $\begin{array}{l}81.1 \pm 0.02 \\
(\mathrm{FW})\end{array}$ & $5.66 \pm 0.02$ & $60.53 \pm 0.01$ & - & $22.74 \pm 0.01$ & [43] \\
\hline Tremella fuciformis & $5.5 \pm 0.18(\mathrm{DW})$ & $6.5 \pm 0.14$ & $13.0 \pm 0.12$ & $2.1 \pm 0.08$ & $72.9 \pm 6.4$ & [39] \\
\hline
\end{tabular}




\section{Nutraceuticals}

Nutraceuticals are a group of products that are more than food but less than pharmaceuticals, in that they can be considered a supplement to effective pharmacological treatment. There is no internationally accepted definition yet, thus the term nutraceuticals can have various meanings depending on the country [48]. The word "nutraceuticals" was originally coined in 1989 by Stephen De Felice, founder and chairman of the Foundation for Innovation in Medicine [49]. The term nutraceutical refers to a product that must have a beneficial effect on health, proven by clinical testing [50]. Nutraceuticals provide medical or health benefits for the prevention and treatment of disease [51], thus playing a vital role in human health and longevity [52]. They can be delivered to the consumer as a dietary supplement and/or as a functional food. The nutraceutical industry encompasses three main segments, which include functional foods, dietary supplements, and herbal/natural products. Nutraceuticals are not proposed as an alternative to drugs, but can be helpful to complement a pharmacological therapy and help in preventing the onset of chronic diseases in subjects who do not qualify for conventional pharmacological treatment [50]. Many clinical studies have been carried out to support the effectiveness, as well as the general safety of many nutraceuticals. However, since nutraceuticals can be used even without the approval of authorities, there are certain risks associated with their consumption, such as the possibility of dangerous interactions with medications, especially in vulnerable populations [48].

Although around 270 species of mushrooms have medicinal properties [11], only a handful are considered as nutraceuticals. Species that are most commonly found in dietary supplements include: A. bisporus (button mushroom), O. sinensis (cordyceps), G. lingzhi (Reishi), Grifola frondosa (maitake), Hericium erinaceus (lion's mane), L. edodes (shiitake), and Trametes versicolor (turkey tail) [5,53]. Many edible mushrooms may still be classified as nutraceuticals in the near future. Such future discoveries are likely since many mushroom species that have been utilized traditionally by different cultures throughout the world for prevention and treatment of many diseases remain to be scientifically studied. "Mushroom nutraceuticals" [54] was coined since mushrooms were used even in ancient times in the form of extracts, health tonics, concentrates, fermented beverages, tinctures, teas, soups, herbal formulas, powders, and healthy food dishes. In addition to nutritional contents, many studies have documented the bioactivities of mushrooms with pharmaceutical potential in the last decades, describing mushrooms as mini pharmaceutical factories of bioactive compounds [55]. These remarkable discoveries have drawn attention outside of the scientific community to the use of mushrooms as bioactive ingredients in functional food products that can increase the nutritional qualities of these products. Examples of food considered to potentially benefit from macrofungi include: bread, muffins, pasta, patties, and snacks [56-58]. Other processed food products have also been incorporated with mushrooms, thus increasing the popularity of mushrooms among consumers. As a consequence, the awareness of the healthful benefits of incorporating mushrooms in the diet has increased. Currently, around $5 \mathrm{~kg}$ of mushrooms are consumed per person per year, and this is expected to increase in the years to come [53].

Species that produce secondary metabolites that have a wide range of biological activities are considered as medicinal macrofungi [59]. Many studies have documented the medicinal properties of mushrooms, including antitumor [60], immunomodulating, antioxidant [61], radical scavenging, cardiovascular-protective [62], antihypercholesterolemia, antiviral, antibacterial, antiparasitic, antifungal, detoxifying, hepatoprotective, and antidiabetic effects [63]. Many polysaccharides or polysaccharide-protein complexes exhibit antitumor activities in animals and humans by enhancing innate and cell-mediated immune response [60]. 


\section{Bioactive Compounds from Macrofungi and Their Medicinal Properties \\ 4.1. Mushroom Species Containing Bioactive Polysaccharides}

Polysaccharides are the most potent substance derived from mushrooms and are responsible for various physiological activities, like antitumor, immunomodulatory, antioxidant, antiviral, anti-inflammatory, anticarcinogenic, and neuroprotective activities [19,22]. Many studies have documented that some sugars produced by mushrooms, such as rhamnose, xylose, fucose, arabinose, fructose, glucose, mannose, mannitol, sucrose, maltose, and trehalose, possess bioactivities [5]. Biologically active polysaccharides (glucans derivatives) produced from macrofungi exhibit various structures with different properties [60]. The antitumor activity of polysaccharides depends primarily on their chemical structures. Many glycans, which are homopolymers to highly complex heteropolymers, exhibit antitumor activities. These compounds activate the immune response of the host organisms. Thus, the antitumor activity is indirectly targeting the tumor cells. The compounds prevent stress in the body, which helps in the reduction of tumor cells and increased survival rate of tumor-induced mice $[64,65]$. Table 2 lists some important macrofungi and the bioactivities of polysaccharides from experimental studies.

Table 2. Experimental in vivo and in vitro studies over the last 5 years (2016-2021) of bioactive polysaccharides from economically important macrofungi.

\begin{tabular}{|c|c|c|c|c|}
\hline Mushroom Species & Name of Fraction(s) & Bioactivity & $\begin{array}{l}\text { Target } \\
\text { Cells/Experimental } \\
\text { Subjects }\end{array}$ & References \\
\hline \multirow[t]{6}{*}{ Agaricus bisporus } & $\begin{array}{l}\text { Agaricus bisporus neutral } \\
\text { polysaccharides (Abnp1001 and } \\
\text { Abnp1002) and Agaricus bisporus } \\
\text { all polysaccharides (Abap1001, } \\
\text { and Abap1002) }\end{array}$ & $\begin{array}{l}\text { Hepato-protective } \\
\text { activity }\end{array}$ & $\begin{array}{l}\mathrm{CCl}_{4} \text {-induced hepatic } \\
\text { injury in mice }\end{array}$ & [7] \\
\hline & $\begin{array}{l}\text { AlAPS and their three purified } \\
\text { fractions (AlAPS-1, AlAPS-2, and } \\
\text { AlAPS-3) }\end{array}$ & $\begin{array}{l}\text { Antiaging, antioxidant, } \\
\text { and hepatoprotective } \\
\text { effects, prevent } \\
\text { age-related diseases }\end{array}$ & $\begin{array}{l}\text { Fresh liver and blood } \\
\text { samples of male } \\
\text { Kunming strain mice }\end{array}$ & [66] \\
\hline & $\begin{array}{l}\text { Mannogalactoglucan } \\
\text { polysaccharide }\end{array}$ & $\begin{array}{l}\text { Antitumor activity } \\
\text { (lung cancer) }\end{array}$ & $\begin{array}{l}\text { Human hepatocarcinoma } \\
\text { cells (HepG2) }\end{array}$ & {$[67]$} \\
\hline & $\begin{array}{l}\text { AcAPS and its major purified } \\
\text { fractions (AcAPS-1, AcAPS- } 2 \text { and } \\
\text { AcAPS-3) }\end{array}$ & $\begin{array}{l}\text { Antiaging and } \\
\text { antioxidant effects }\end{array}$ & $\begin{array}{l}\text { Fresh liver and kidney } \\
\text { samples of male } \\
\text { Kunming strain mice }\end{array}$ & [68] \\
\hline & $\begin{array}{l}\text { Agaricus bisporus fruiting body } \\
\text { polysaccharide (FPS) }\end{array}$ & $\begin{array}{l}\text { Hepato-protective } \\
\text { activity }\end{array}$ & $\begin{array}{l}\mathrm{CCl}_{4} \text {-induced liver injury } \\
\text { in mice }\end{array}$ & [69] \\
\hline & $\begin{array}{l}\text { Glucogalactomanan } \\
\text { polysaccharide TJ3 }\end{array}$ & $\begin{array}{l}\text { Immunostimulatory } \\
\text { activity }\end{array}$ & RAW 264.7 cells & [70] \\
\hline \multirow[t]{5}{*}{$\begin{array}{l}\text { Ganoderma lingzhi/G. } \\
\text { sichuanense (as } \\
\text { Ganoderma lucidum) }\end{array}$} & $\begin{array}{l}\text { Ganoderma lucidum } \\
\text { polysaccharides (GLP) }\end{array}$ & $\begin{array}{l}\text { Immunomodulatory } \\
\text { effect }\end{array}$ & $\begin{array}{l}\text { Mice immunized with } \\
\text { GLPL/OVA }\end{array}$ & [71] \\
\hline & GLP & $\begin{array}{l}\text { Antitumor activity } \\
\text { (colorectal cancer) }\end{array}$ & $\begin{array}{l}\text { Colorectal cancer HT29 } \\
\text { (p53R273H) and SW480 } \\
\text { (p53R273H\&P309S) cells }\end{array}$ & [72] \\
\hline & GLP & Neuroprotective effects & $\begin{array}{l}\text { Rat cerebellar granule } \\
\text { cells (CGCs) }\end{array}$ & [73] \\
\hline & GLP & $\begin{array}{l}\text { Anticancer activity } \\
\text { (prostate cancer) }\end{array}$ & $\begin{array}{l}\text { Human prostate cancer } \\
\text { cells LNCaP }\end{array}$ & [74] \\
\hline & GLP & $\begin{array}{l}\text { Antitumor (brain } \\
\text { glioma) and } \\
\text { immunomodulatory } \\
\text { activities }\end{array}$ & Glioma-bearing rats & [75] \\
\hline
\end{tabular}


Table 2. Cont

\begin{tabular}{|c|c|c|c|c|}
\hline Mushroom Species & Name of Fraction(s) & Bioactivity & $\begin{array}{l}\text { Target } \\
\text { Cells/Experimental } \\
\text { Subjects }\end{array}$ & References \\
\hline & GLP & Hypoglycemic effect & $\begin{array}{l}\text { Type } 2 \text { diabetes mellitus } \\
\text { (T2DM) rats' blood liver } \\
\text { and skeletal muscles }\end{array}$ & [76] \\
\hline & $\begin{array}{l}\text { Degraded Ganoderma lucidum } \\
\text { polysaccharides (GLP }\end{array}$ & $\begin{array}{l}\text { Hypolipidemic and } \\
\text { antioxidant activities }\end{array}$ & $\begin{array}{l}\text { Blood, heart, spleen, liver } \\
\text { and kidney of male } \\
\text { Kunming mice }\end{array}$ & [77] \\
\hline & GLP & Antidiabetic activity & T2DM rats' blood & [78] \\
\hline \multirow[t]{4}{*}{ Grifola frondosa } & $\begin{array}{l}\text { Grifola frondosa polysaccharides } \\
\text { (GFP) }\end{array}$ & $\begin{array}{l}\text { Anticancer activity } \\
\text { (breast cancer) }\end{array}$ & $\begin{array}{l}\text { MCF-7 and } \\
\text { MDA-MB-231 cells, as } \\
\text { well as in nude mice } \\
\text { bearing MCF-7 tumor } \\
\text { xenografts. }\end{array}$ & [79] \\
\hline & GFP & $\begin{array}{l}\text { Memory enhancement } \\
\text { and antiaging activities }\end{array}$ & 20-month-old rats & [80] \\
\hline & GFP-N & $\begin{array}{l}\text { Hypoglycemic and } \\
\text { prebiotic activities }\end{array}$ & Diabetic mouse livers & [81] \\
\hline & GFP & $\begin{array}{l}\text { Hypoglycemic and } \\
\text { hypolipidemic } \\
\text { activities }\end{array}$ & $\begin{array}{l}\text { Diabetic mice induced by } \\
\text { HFD and streptozotocin } \\
\text { (STZ) }\end{array}$ & [82] \\
\hline \multirow[t]{6}{*}{ Hericium erinaceus } & $\begin{array}{l}\text { Hydroxyethylated derivative of } \\
\text { HEP }\end{array}$ & $\begin{array}{l}\text { Immunomodulatory } \\
\text { activities }\end{array}$ & RAW264.7 macrophages & [83] \\
\hline & Selenium derivatives (sHEPs) & $\begin{array}{l}\text { Immunostimulant } \\
\text { activity }\end{array}$ & Dendritic cells & [84] \\
\hline & $\begin{array}{l}\text { Hericium erinaceus crude } \\
\text { polysaccharide (HECP) and } \\
\text { Hericium erinaceus refined } \\
\text { polysaccharide (HERP) }\end{array}$ & $\begin{array}{l}\text { Gastroprotective } \\
\text { activity }\end{array}$ & $\begin{array}{l}\text { Sprague-Dawley rats' } \\
\text { stomach }\end{array}$ & [85] \\
\hline & $\begin{array}{l}\text { Novel Hericium erinaceus } \\
\text { polysaccharide } \mathrm{HEP}_{\mathrm{N}}\end{array}$ & $\begin{array}{l}\text { Gastroprotective } \\
\text { activity }\end{array}$ & $\begin{array}{l}\text { Human gastric } \\
\text { epithelium (GES-1) cells }\end{array}$ & [86] \\
\hline & $\begin{array}{l}\text { Hericium erinaceus fruiting body } \\
\text { polysaccharide (HEFP)- } 2 \mathrm{~b}\end{array}$ & $\begin{array}{l}\text { Anticancer activity } \\
\text { (colon cancer) }\end{array}$ & $\begin{array}{l}\text { Colon cancer cells } \\
\text { (HCT-116) }\end{array}$ & [87] \\
\hline & $\begin{array}{l}\text { Enzymatic hydrolysis of Hericium } \\
\text { erinaceus polysaccharide (EHEP) }\end{array}$ & $\begin{array}{l}\text { Immune-enhancement } \\
\text { activity }\end{array}$ & Female Balb/c mice & [88] \\
\hline \multirow[t]{7}{*}{ Lentinula edodes } & $\begin{array}{l}\text { Mannogalactoglucan-type } \\
\text { polysaccharides (WPLE-N-2 and } \\
\text { WPLE-A0.5-2) }\end{array}$ & $\begin{array}{l}\text { Anticancer and } \\
\text { immunomodulating } \\
\text { activities }\end{array}$ & $\begin{array}{l}\text { Sarcoma 180-bearing } \\
\text { mice }\end{array}$ & {$[64]$} \\
\hline & Myeloid-derived suppressor cells & $\begin{array}{l}\text { Immunosuppressive } \\
\text { effects }\end{array}$ & $\begin{array}{l}\text { Immortalized myeloid } \\
\text { immune suppressor cell } \\
\text { line (MSC2) }\end{array}$ & [89] \\
\hline & $\begin{array}{l}\text { Lentinula edodes polysaccharide } \\
\text { (LEP) } 1\end{array}$ & Antitumor activity & $\begin{array}{l}\text { Human cervical } \\
\text { carcinoma HeLa cells }\end{array}$ & [90] \\
\hline & $\begin{array}{l}\text { Residue polysaccharide (RPS) and } \\
\text { its enzymatic-RPS (ERPS) }\end{array}$ & $\begin{array}{l}\text { Antioxidant and } \\
\text { anti-inflammatory } \\
\text { activities }\end{array}$ & $\begin{array}{l}\text { LPS-induced sepsis in } \\
\text { mice }\end{array}$ & [91] \\
\hline & LEP & $\begin{array}{l}\text { Anticancer (colon } \\
\text { cancer) }\end{array}$ & HT-29 colon cancer cells & [85] \\
\hline & $\begin{array}{l}\text { Acidic spent mushroom compost } \\
\text { polysaccharides (ASMCP) }\end{array}$ & $\begin{array}{l}\text { Antioxidant, } \\
\text { anti-inflammatory and } \\
\text { renoprotective effects }\end{array}$ & LPS-induced KI in mice & [92] \\
\hline & $\begin{array}{l}\text { Polysaccharide fractions (F1, F2 } \\
\text { and F3) }\end{array}$ & $\begin{array}{l}\text { Immunomodulatory } \\
\text { effects }\end{array}$ & Female BALB/c mice & [93] \\
\hline
\end{tabular}


Table 2. Cont.

\begin{tabular}{|c|c|c|c|c|}
\hline Mushroom Species & Name of Fraction(s) & Bioactivity & $\begin{array}{l}\text { Target } \\
\text { Cells/Experimental } \\
\text { Subjects }\end{array}$ & References \\
\hline \multirow[t]{6}{*}{$\begin{array}{l}\text { Ophiocordyceps } \\
\text { sinensis (as Cordyceps } \\
\text { sinensis) }\end{array}$} & $\begin{array}{l}\text { Cordyceps sinensis polysaccharide } \\
\text { (CSP1-2) }\end{array}$ & Antihypertensive effect & $\begin{array}{l}\text { Spontaneously } \\
\text { hypertensive rats (SHR) }\end{array}$ & [94] \\
\hline & CPS-A & Protective effect & L02 cells & [95] \\
\hline & CSP & Prebiotics & $\begin{array}{l}\text { Cyclophosphamide } \\
(\mathrm{Cy}) \text {-induced intestinal } \\
\text { mucosal } \\
\text { immunosuppression and } \\
\text { microbial dysbiosis in } \\
\text { mice }\end{array}$ & {$[96,97]$} \\
\hline & CSP & Anti-obesity & $\begin{array}{l}\text { High-fat diet } \\
\text { (HFD)-feeding C57BL/6J } \\
\text { mice }\end{array}$ & [98] \\
\hline & $\begin{array}{l}\text { Docetaxel-loaded acetic acid } \\
\text { conjugated Cordyceps sinensis } \\
\text { polysaccharide (DTX-AA-CSP) }\end{array}$ & $\begin{array}{l}\text { Drug carrier and } \\
\text { anticancer (liver and } \\
\text { colon cancers) }\end{array}$ & $\begin{array}{l}\text { Human umbilical vein } \\
\text { endothelial cells; human } \\
\text { liver HepG2; colon } \\
\text { cancer cells SW480 }\end{array}$ & [99] \\
\hline & CSP & $\begin{array}{l}\text { Anticancer activity } \\
\text { (colon cancer) }\end{array}$ & $\begin{array}{l}\text { Colon cancer cell line } \\
\text { HCT116 }\end{array}$ & [100] \\
\hline \multirow[t]{5}{*}{ Pleurotus eryngii } & $\begin{array}{l}\text { Pleurotus eryngii polysaccharides } \\
\text { PEP-1 and PEP-2 }\end{array}$ & Antitumor & $\begin{array}{l}\text { Human hepatoblastoma } \\
\text { HepG-2 cells }\end{array}$ & [101] \\
\hline & $\begin{array}{l}\text { Pleurotus eryngii polysaccharide } \\
\text { (PEP) }\end{array}$ & $\begin{array}{l}\text { Hypolipidemic and } \\
\text { hypoglycemic activities }\end{array}$ & $\mathrm{KK}-\mathrm{A}^{\mathrm{y}}$ mice & [102] \\
\hline & $\begin{array}{l}\text { water-soluble polysaccharide } \\
\text { EPA-1 }\end{array}$ & $\begin{array}{l}\text { Immunoregulatory } \\
\text { activity }\end{array}$ & RAW 264.7 cells & [103] \\
\hline & PEP & Hypolipidemic effect & $\begin{array}{l}\text { Mice with } \\
\text { hyperlipidemia }\end{array}$ & [104] \\
\hline & PEP & Neuroprotective effect & $\begin{array}{l}\beta \text {-amyloid-induced } \\
\text { neurotoxicity in cultured } \\
\text { rat pheochromocytoma } \\
\text { (PC12) cells }\end{array}$ & [105] \\
\hline \multirow[t]{6}{*}{ Pleurotus ostreatus } & $\begin{array}{l}\text { Pleurotus ostreatus polysaccharide } \\
\text { (POP) }\end{array}$ & $\begin{array}{l}\text { Regulating } \\
\text { dyslipidemia effect }\end{array}$ & STZ-induced diabetic rats & [106] \\
\hline & POP & Anticancer activity & Sarcoma 180 tumor cells & [107] \\
\hline & POP & $\begin{array}{l}\text { Regulating } \\
\text { dyslipidemia effect }\end{array}$ & $\begin{array}{l}\text { Fat-emulsion-induced } \\
\text { hyperlipidemia rats }\end{array}$ & [108] \\
\hline & POP & $\begin{array}{l}\text { Anticancer (lymphoid } \\
\text { cancer) }\end{array}$ & $\begin{array}{l}\text { Murine lymphoid cancer } \\
\text { cell line }\end{array}$ & [109] \\
\hline & $\begin{array}{l}\text { Selenium polysaccharide fraction } \\
\text { (Se-POP-3) }\end{array}$ & Antitumor activity & $\begin{array}{l}\text { Human cancer cell lines } \\
\text { HepG2, MCF-7, SKOV3, } \\
\text { HeLa, and PC-3 }\end{array}$ & [110] \\
\hline & $\begin{array}{l}\text { Phosphorylated Pleurotus ostreatus } \\
\text { polysaccharide (PPOP) }\end{array}$ & Hepatoprotective effect & $\begin{array}{l}\text { Carbon } \\
\text { tetrachloride-induced } \\
\text { liver injury in mice }\end{array}$ & [111] \\
\hline \multirow[t]{3}{*}{ Trametes versicolor } & Polysaccharopeptides PSPs-EH80 & Antioxidative effect & HaCaT cells & [112] \\
\hline & $\begin{array}{l}\text { Trametes versicolor polysaccharide } \\
\text { (TVP) }\end{array}$ & $\begin{array}{l}\text { Anti-proliferative and } \\
\text { anti-invasive effects }\end{array}$ & $\begin{array}{l}\text { LoVo and HT- } 29 \text { human } \\
\text { colon cancer cells }\end{array}$ & [113] \\
\hline & $\begin{array}{l}\text { Intracellular polysaccharide } \\
\text { extract of Trametes versicolor (IPTV) } \\
\text { and extracellular polysaccharide } \\
\text { extracts of T. versicolor (EPTV) }\end{array}$ & $\begin{array}{l}\text { Antihyperlipidemic } \\
\text { effects }\end{array}$ & $\begin{array}{l}\text { HFD-induced } \\
\text { hyperlipidemic mice }\end{array}$ & [114] \\
\hline
\end{tabular}

Agaricus bisporus polysaccharides have antiaging activity, and can protect hepatic and renal functions by improving serum enzyme activities, biochemical levels, lipid contents, and antioxidant status $[66,115,116]$. ABP- 1 and ABP-2 fractions of polysaccharides demon- 
strated antitumor activity by inhibiting the growth of human breast cancer MCF-7 cells and reducing the growth of murine sarcoma 180 cells implanted subcutaneously into mice [117]. AlAPS and AcAPS and their major purified fractions have antiaging and antioxidant effects. Specifically, AcAPS-2 showed scavenging activity on hydroxyl $(82.98 \pm 4.67 \%)$ and DPPH (64.47 $\pm 4.05 \%)$ radicals at the concentration of $1.0 \mathrm{mg} / \mathrm{mL}$ in vitro [68]. Both AlAPS and AcAPS demonstrated hepatic and nephric protection activities by improving serum enzyme activity, biochemical levels, lipid contents, and antioxidant status $[66,68]$. ABP and fractions Abnp1002 and Abap1002 also demonstrated hepato-protective activity against $\mathrm{CCl}_{4}$-induced hepatic injury in mice [7,69]. The mannogalatoglucan extracted and characterized from $A$. bisporus showed antitumor activity against human hepatocarcinoma cells (HepG2) by inducing apoptosis via the mitochondrial death pathway [67]. ABP also showed immunostimulatory effects in RAW 264.7 cells [70].

Ganoderma spp. polysaccharides are also very promising nutraceuticals with multiple bioactivities, such as anti-angiogenesis, antidiabetic, antioxidation, antiproliferation, hepatoprotection, and immunomodulation [118]. GLP has been shown to prevent glioma growth in glioma-bearing rats by increasing the concentration of serum interleukin-2, tumor necrosis factor- $\alpha$, and interferon- $\gamma$, as well as enhance the cytotoxic activity of natural killer cells and T cells [75]. It also exerts antitumor activity via MAPK pathways in HL-60 acute leukemia cells [119]. GLP also inhibited the proliferation of colorectal cancer HT29 (p53R273H) and SW480 (p53R273H\&P309S) cells using the p53-mediated tumor-suppressing pathways [72]. Furthermore, GLP suppressed the growth and migration of LNCaP human prostate cancer cells [74]. GLP also inhibited the accumulation of myeloid-derived suppressor cells (MDSC) via the CARD9-NF-kB-IDO pathway, thus preventing lung cancer development [120]. Polysaccharides from G. lingzhi/G. sichuanense (as G. lucidum) were also shown to promote cognitive function and neural progenitor proliferation in a mouse model of Alzheimer's disease [121] and had a neuroprotective effect by regulating the expression of apoptosis-associated proteins, inhibiting oxidative stressinduced neuronal apoptosis [73]. GLPs also had hypoglycemic effects in diabetic mouse models (T2DM), in which glucose levels and lipid metabolism were improved [76,78]. However, degraded polysaccharide, GLP $\mathrm{UD}_{\mathrm{D}}$, was proven to have stronger hypolipidemic and antioxidant activities than GLP in mice, which could significantly improve lipid metabolism disorders in hepatocytes [77].

Grifola frondosa polysaccharides are also very promising antitumor agents. In fact, a G. frondosa polysaccharide-based drug was developed in China and approved as an adjunctive therapeutic drug for cancer treatment [122]. The cancer-fighting ability of GFP was superior to polysaccharides from G. sichuanense, lentinan, and Trametes versicolor [122]. Many studies have demonstrated the inhibitory effects of polysaccharides from $G$. frondosa mycelial extracts on different cancer-cell-bearing mice. GFP inhibited the growth of LoVo and HT-29 human colon cell proliferation and induced cytotoxicity [113]. It also exerted cytotoxic effects on the MCF-7 and MDA-MB-231 cells, as well as in nude mice bearing MCF-7 tumor xenografts, as indicated by a decrease in cell viability, increase in the apoptotic rate, and induced mitochondrial dysfunction supporting its potential application to cure breast cancer [79]. Aside from anticancer activity, GFP also showed hypoglycemic and hypolipidemic activities. A study in diabetic mice induced by HFD and STZ administered with GFP showed reduced sugar and lipid levels in the blood by altering gut microbiota [82]. Grifola frondosa polysaccharide-N (GFP-N) also demonstrated hypoglycemic effects in diabetic mouse livers [81]. GFP administration also significantly improved memory impairment in aged rats via antioxidant action, thus can be a good dietary supplement for brain aging [80].

Similar to other macrofungi discussed so far, Hericium erinaceus polysaccharides (HEP) also possess various bioactivities. They have been extensively studied for potential and existing applications in pharmaceuticals and functional foods [29]. The different polysaccharides isolated from this species are galactoxyloglucans, glucoxylans, hetero-xyloglucans, and xylans [123]. Hericium erinaceus exhibit antitumor, immunomodulatory, antioxidative, gastroprotective, neuroprotective, neuroregenerative, hypolipidemic, hypoglycemic, antifa- 
tigue and antiaging properties [124]. Bioactive compounds extracted from the mycelia and fruiting bodies of $H$. erinaceus have been found to promote nerve growth factors accompanying cell proliferation [125]. They improve recognition memory [126] and have been used to treat cognitive impairment, Parkinson's disease, and Alzheimer's disease by promoting the expression of neurotrophic factors that are associated with cell proliferation, such as nerve growth factors [125]. The enzymatic modification of HEP (EHEP) significantly enhanced phagocytosis of NO, CD40, and CD86 positive cells by peritoneal macrophages, thus enhancing the immunomodulation function of HEP [88]. The hydroxyethylated derivative of HEP also has potential immunomodulatory activities on RAW264.7 peritoneal macrophages [83]. Moreover, sHEPs also showed strong immunostimulant activity by inducing dendritic cell maturation through MAPK and NF- $\mathrm{B}$ signaling pathways [84]. Pretreatment of HEP also reduced ethanol-induced gastric mucosal lesions and pylorus ligation-induced gastric ulcers in mice, which is further evidence for its gastroprotective activity [85]. A novel polysaccharide from $H$. erinaceus $\left(\mathrm{HEP}_{\mathrm{N}}\right)$ also exhibited gastroprotective activity by preventing $\mathrm{H}_{2} \mathrm{O}_{2}$-induced oxidative stress from damaging human gastric epithelium (GES-1) cells by promoting cell proliferation, inhibiting cell necrosis, reducing ROS levels, regulating mitochondrial membrane potential, and maintaining mitochondrial membrane permeability [86]. The novel polysaccharide HEFP-2b also inhibited the growth of colon cancer cells (HCT-116) in vitro by arresting it in the S-phase of the cell cycle [87].

Lentinula edodes polysaccharides show antitumor activity against human cervical carcinoma HeLa cells, causing an inhibitory effect on their proliferation and induced apoptotic death [90]. They also inhibit the proliferation of HT-29 colon cancer cells and suppress the growth of tumors in athymic nude mice [127]. LEP impairs the immunosuppressive function of myeloid-derived suppressor cells via the p38 pathways [89]. The mannogalactoglucan-type polysaccharides (WPLE-N-2 and WPLE-A0.5-2) from. L. edodes exhibit anticancer and immunomodulating activities on sarcoma 180 (S-180)-bearing mice [64]. LEPs are also known for their immunomodulatory effects. The three fractions of LEP (F1, F2, and F3) demonstrated immunomodulatory effects through enhancing cellular immunity by increasing the thymus index, DTH, and proliferation of T splenocytes [93]. RPS and ERPS of L. edodes also exhibit antioxidative, anti-inflammatory, and organ protective effects against the LPS-induced sepsis in mice, which makes them suitable for functional foods and treatment of sepsis and its complications [91]. The acidic spent mushroom compost polysaccharides (ASMCP) also have antioxidant, anti-inflammatory, and renoprotective effects against LPS-induced KI in mice [92].

Ophiocordyceps sinensis polysaccharides are also a very promising source of bioactive polysaccharides with anticancer, antihypertensive, anti-inflammatory, anti-obesity, and antioxidant activities, as well as drug delivery capacity, and can also help as a prebiotic. The docetaxel-loaded acetic acid conjugated $O$. sinensis polysaccharide (DTX-AA-CSP) was demonstrated to have antitumor activity in vivo against human liver (HepG2) and colon cancer cells (SW480), which was even more effective than the currently marketed treatment of docetaxel injection $\left(\right.$ Taxotere $^{\circledR}$ ) [99]. CSP also significantly inhibited the proliferation of human colon cancer cell line HCT116 cells, resulting in increased autophagy and apoptosis [100]. CPS-A also showed a good protective effect on angiotensin (Ang II)induced L02 cell injury [95]. CSP1-2 fraction also demonstrated an antihypertensive effect on spontaneously hypertensive rats (SHR) by stimulating the secretion of vasodilator NO, decreasing the level of ET-1, epinephrine, noradrenaline, and angiotensin II, inhibiting the increase of transforming growth factor $\beta 1$ (TGF- $\beta 1$ ) and lowering the level of inflammatory mediator of C-reactive protein (CRP) [94]. CSP soluble dietary fiber had protective effects against obesity on HFD-feeding C57BL/6J mice; however, the study also showed that, though CSP could prevent the increase in body weight, it could also result in aggravated liver fibrosis and steatosis [98]. CSP has also been shown to improve microbial community diversity and modulated the overall structure of gut microbiota, thus can be a potential prebiotic agent $[96,97]$. 
Pleurotus eryngii polysaccharides inhibit the growth of human hepatoblastoma HepG2 cells [101]. PEP isolated and purified also possessed good immunoregulatory activity in vivo, and stimulated the production of NO and cytokines by MAPK and NF-KB [103]. PEP extracted with hot water exhibited hypolipidemic and hypoglycemic activities, measured by decreased body weight gain, levels of plasma insulin, serum triglyceride, lowdensity lipoprotein cholesterol, and blasting blood glucose in mice, and thus could be explored as a possible therapeutic agent for hyperlipidemia and hyperglycemia [102]. High-dose PEP treatment also had lipid-lowering and liver protection effects on mice with hyperlipidemia [128]. PEP also significantly elevated cell viability, reduced the levels of intracellular calcium, and decreased $\beta$-amyloid-mediated cell apoptosis in PC12 cells of mice, thus represents a possible therapeutic approach to ameliorate the onset and progression of Alzheimer's disease [105].

Pleurotus ostreatus polysaccharides have more diverse bioactivities. Numerous animal studies with P. ostreatus documented the hypoglycemic, hypolipidemic, and antioxidant effects [108]. These polysaccharides can also reduce hyperglycemia and hyperlipidemia levels in STZ-induced diabetic rats by improving insulin resistance and increasing glycogen storage [129]. POP also regulated dyslipidemia of hyperlipidemia rats [108], thus lowering the chance of having premature atherosclerosis, which could lead to angina or heart attack. Moreover, POP can alleviate cognitive impairment in rats, suggesting that these polysaccharides can help cure Alzheimer's disease [106]. Consumption of P. ostreatus may improve glucose and lipid metabolism, blood pressure, body weight, and appetite sensations [130]. PPOP exhibited stronger hepatoprotective effects and stronger antioxidant activity in vivo when compared to unphosphorylated POP [111]. Different studies also demonstrated the antitumor and anticancer activities of POP against targeted cells. POP has cytotoxic activity when applied to murine lymphoid cancer cell line [109] and sarcoma 180 tumor cells [107]. A novel selenium polysaccharide fraction (Se-POP-3) can also can induce apoptosis and inhibit migration of cancer cells [110].

Trametes versicolor polysaccharides also showed numerous bioactivities, especially against different cancer types. The direct toxicity of TVP preparations to cancer/tumor cells has been demonstrated in the various in vitro models, as discussed by Habtemariam [131]. Numerous cancer types were targeted by the polysaccharides isolated from T. versicolor. TVP inhibits human colon cell proliferation and induces cytotoxicity [113]. TVP also had antihyperlipidemic effects in HFD-induced hyperlipidemic mice, improving serum lipid profiles [114]. It can also improve $\mathrm{HaCaT}$ cell survival, owing to its antioxidant property [112].

\subsection{Macrofungal $\beta$-Glucans}

Among the different polysaccharides, $\beta$-glucans are the most abundant in mushrooms, and are found primarily in the fungal cell wall. They are the most versatile metabolite, with a wide spectrum of biological activity [132]. Detailed studies of $\beta$-glucans demonstrated their beneficial impact on human life. These compounds are responsible for many bioactivities, such as immunomodulating, anticholesterolemic, antidiabetic, antioxidant, and neuroprotective activities, as well as lipid balance improvement, and they even have a great impact on the general feeling of the consumer [133]. They bind to a membrane receptor and induce these biological responses [134]. Since $\beta$-glucans are not synthesized by the human body, they therefore induce both innate and adaptive immune responses [135]. Chemical structures of important $\beta$-glucans can be found in Figure 1. 

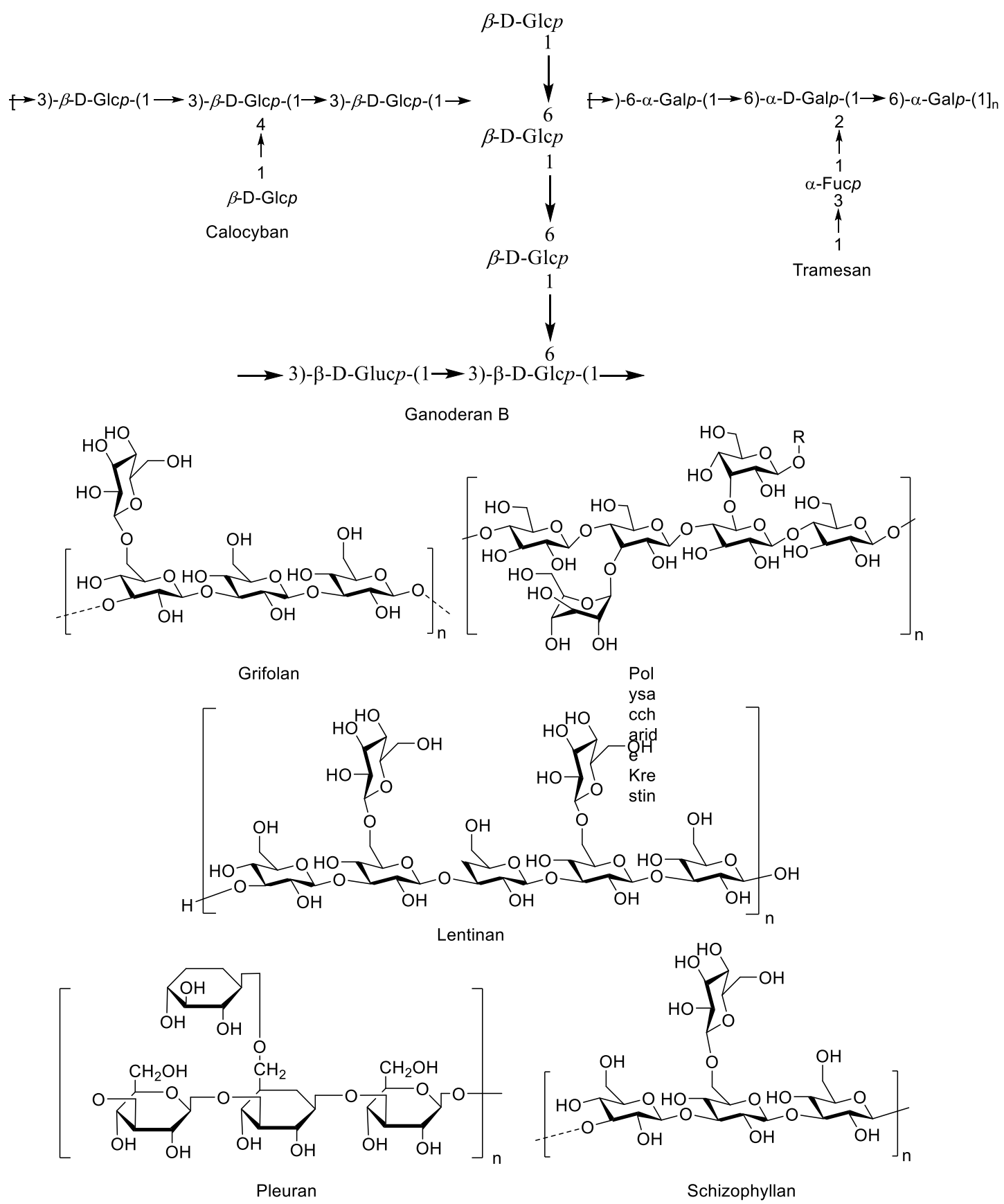

Figure 1. Chemical structures of $\beta$-glucans isolated from some economically important macrofungi.

Calocyban is a polysaccharide isolated from Calocybe indica. Mandal et al. [136] isolated new water-soluble $(1 \rightarrow 6)-,(1 \rightarrow 4)-\alpha$, $\beta$-glucan and water-insoluble $(1 \rightarrow 3)-,(1 \rightarrow 4)$ $\beta$-glucan (calocyban) from alkaline extracts of this mushroom. Extracts of this macrofungus also showed synergistic effects with standard antibiotics. It increased the efficacy of ciprofloxacin against opportunistic pathogenic bacteria [137]. The ethanolic extract of C. indica also exhibited an antiproliferative and apoptotic effect on PANC-1 and MIAPaCa2 cell lines of pancreatic cancer in vitro [138].

Ganoderan is a hypoglycemic polysaccharide derived from the aqueous extract of G. lingzhi/G. sichuanense (as G. lucidum) [139]. The ganoderans A, B, and C were all isolated from this species and demonstrated bioactivity against non-small-cell lung carcinoma (NSCLC), and had the effects of hyperglycemic and kidney protection [140,141]. Many studies have been documented on the bioactivities of ganoderans. The study of Wang et al. [140] 
showed that ganoderan B can be used to inhibit growth of H510A and A549 cells by suppressing the expression of ki67 and proliferating cell nuclear antigen (PCNA), thus it can be effective in suppressing NSCLC tumor formation and metastasis. Ganoderan B promotes apoptosis of H510A and A549 cells by regulating the expression of Bcl-2, Bax, cleaved caspase 3, and cleaved poly (adenosine diphosphate-ribose) polymerase (PARP). It also demonstrated hypoglycemic activity by increasing the plasma insulin level in normal and glucose-loaded mice [142]. Moreover, the ganoderans obtained from the mycelial fractionation of G. lingzhi/G. sichuanense (as G. lucidum) IY009 also exhibit immunomodulating effects. The ganoderan isolated from the cell wall of G. lingzhi/G. sichuanense IY009 showed the highest antitumor activity (inhibition rate of $94 \%$ ) in sarcoma-bearing mice and $37 \%$ of anticomplementary activity [143].

Grifolan is the polysaccharide, branched (1,3)- $\beta$-glucan, extracted from the fruit body or the mycelium of the fungus G. frondosa [144]. In the earlier study of Takeyama et al. [145], grifolan NMF-5N was shown to have a host-mediated antitumor effect. Although grifolan NMF-5N did not exhibit a direct effect on the tumor cells, intraperitoneal injection of this compound increased the number of peritoneal exudate cells and peritoneal adherent cells. The increase in number of these cells indicated cytostatic activity towards syngeneic tumor cells. Grifolan as an immune-modulator was also confirmed by Ishibashi et al. [146], where it activated macrophages to produce tumor necrosis factor (TNF) in vitro. $\beta$-glucan, isolated by Seo et al. [147] also showed immunostimulatory activity, confirmed through cell activation ability and cytokine expression. In accordance with the molecular evidence suggesting the polysaccharides from this fungus may have health benefits, in Asia, G. frondosa or maitake are consumed and recommended to treat various diseases, such as arthritis, hepatitis, and HIV [148].

Polysaccharide Krestin (PSK) is a $\beta$-glucan-protein complex consisting of $25-38 \%$ protein residues, with a molecular weight of about $94 \mathrm{KDa}$. It is isolated from T. versicolor, demonstrating strong antitumor activity against numerous cancer types and has been used as an adjuvant for cancer treatment with no known side effects [149]. This complex mainly consists of acidic amino acids, such as aspartic acid and glutamic acid, neutral amino acids, such as valine and leucine, and small amounts of basic amino acids, such as lysine and arginine. In the early studies, PSK was shown to have direct effects on the gene expression profile in cancer cells which inhibit hepatic carcinogenesis in rats induced by 3'-methyl-4-dimethylaminoazobenzene [150,151]. PSK has long been used in Asia, and recently in Western countries, as a treatment for cancer due to its presumed immune potentiating effects [152]. Coriolan as a $\beta-(1 \rightarrow 3)$ polysaccharide with some $(1 \rightarrow 6)$ and no $(1 \rightarrow 4)$ branched glucan, also isolated from T. versicolor, showed to be effective $(100 \mathrm{mg} / \mathrm{kg}$ for 30 days) in suppressing sarcoma 180 tumors in mice [153].

Lentinan is a $\beta$-glucan isolated from $L$. edodes. The structure of lentinan is composed of a $\beta$-(1-3)-glucose backbone with two (1-6)- $\beta$-glucose branches of each five glucose units [154]. Many clinical studies have verified the efficacy of lentinan to treat various cancers, such as colorectal cancer, gastric cancer, lung cancer, and ovarian cancer. Lentinan demonstrated antioxidative, antitumor (fibrosarcoma), and antimetastatic activities [154-157], immune potentiating activity [158,159], anti-inflammatory [156], and even antimicrobial activity [160].

Since 1985, lentinan has been used in Japan as an adjuvant for stomach cancer therapy [161]. A case of recurrent ovarian cancer successfully treated with adoptive immunotherapy and lentinan has been reported by Fujimoto et al. [162]. In general, the indirect anticancer, as well as immunostimulatory effects of lentinan have been attributed to the activation of many immune cells [163]. Lentinan can increase the engulfing ability of certain immune cells to search and destroy migratory cancer cells in the human body [164]. Specifically, lentinan can activate immunocytes (NK, macrophage, $\mathrm{T}$ cells) by triggering MAPK-NF-KB and Syk-PKC into binding with recognition receptors, such as TLR2/4/6/9, Dectin-1, and other membrane receptors [157]. Lentinan also activates the NRF2-ARE signaling pathway to prevent cis-DDP-induced kidney injury in vivo [165]. 
Lentinan also has antibacterial activity against Mycobacterium tuberculosis [166] and Listeria monocytogenes [167]. This $\beta$-glucan also helps in improving the bactericidal ability of peritoneal and alveolar macrophages [168]. It has immunomodulating effects against the Newcastle disease virus [169] and malarial infection [170], thus can be developed into antiviral and antimalarial drugs. Lentinan based drugs can also be used for treating HIV [171,172], hepatitis, and malignant pleural effusion [154]. Studies on chemotherapy combined with lentinan exhibited better efficacy and response rates than chemotherapy alone in treating different kinds of cancer [157]. The adverse effects of chemotherapy, such as leukopenia, thrombocytopenia, vomiting, etc., were lessened with the supplementation of lentinan, showing a significant improvement in the quality of life and physical condition for patients with breast, colorectal, gastric, gynecological, hepatic, intestinal, and lung cancers, and lymphoma [157]. Clinical data compiled in the past 12 years and presented in the review by Zhang et al. [158] showed that lentinan is effective not only in improving quality of life, but also in promoting the efficacy of chemotherapy during lung cancer treatment.

Pleuran, the $\beta$-glucan $(\beta-(1,3 / 1,6)$-D-glucan) produced by the P. ostreatus, has also demonstrated biological response modifier properties. It has proven to be an effective supplement to increase the immunity of athletes, even for intensive training [173]. This $\beta$-glucan was found to be effective against upper respiratory tract infections $[174,175]$. Pleuran has also been shown to have antiviral activity against herpes simplex virus type 1 (HSV-1). Another study [176] showed promising results in the clinical and immunomodulatory effects of pleuran-based supplements against HSV-1. Active treatment with pleuran in systemic application caused a significantly shorter duration of herpes simplex symptoms compared to a placebo group. Moreover, pleuran demonstrated effectiveness against acute respiratory symptoms, with the duration and severity of respiratory symptoms lower in the pleuran applied group compared to the placebo group.

Schizophyllan is a nonionic, water-soluble homoglucan, neutral extracellular polysaccharide, $\beta$-(1-6)-branched $\beta$-(1-3)-glucan, produced by the fungus Schizophyllum commune [177]. It has numerous uses for commercial, nutraceutical, and medicinal applications. Schizophyllan is quite similar to lentinan in its composition, biological activity, and mechanism of immunomodulation and antitumor action [177]. This homoglucan exhibits bioactivities, such as acting as a biological response modifier and nonspecific immuno-stimulator [178]. The antitumor activity of schizophyllan is mainly due to the hostmediated immune response, enhancement of cell-mediated immune response with stimulation of T lymphocytes and macrophages, and improving cytokine production $[177,178]$. It can counter various diseases and help to enhance the effects of vaccines and antitumor therapies [179]. Other reported bioactivities include antineoplastic, antibacterial, and antiparasitic properties [164].

Tramesan is an exopolysaccharide released in the culture filtrate of T. versicolor, which acts as an antioxidant regardless of the biological system to which it is applied [180]. Tramesan can decrease immune system depression, act as an antioxidant, prevent cancer, inhibit growth of Candida albicans, along with having antiviral activity by inhibiting the replication of HIV, and further possessing liver protective functions [181]. It has also been found to induce a marked growth inhibition of leukemic cell lines and primary cells from acute myeloid leukemic patients [182]. Additionally, Tramesan was also found to have agricultural applications. It can be used as a natural alternative to crop protection chemicals for controlling the mycotoxins produced by Aspergillus flavus and A. carbonarius [183]. Finally, this exopolysaccharide inhibits the growth of wheat pathogens, Zymoseptoria tritici and Parastagonospora nodorum [184].

\subsection{Proteins}

Proteins from macrofungi have many pharmaceutical activities and possess immunomodulatory properties, and antitumor, antiviral, antibacterial, and antifungal activities. Bioactive proteins have great value in terms of pharmaceutical potential. Examples of 
such proteins include lectins, fungal immunomodulatory proteins, ribosome inactivating proteins, antimicrobial proteins, and ribonucleases [185].

Lectins are carbohydrate binding proteins that can aggregate immunoglobulins and may be involved in sugar transport or carbohydrate storage in the cell [186]. They are present in the mushroom fruiting bodies with important roles in the life cycle of these fungi [187]. Lectins manifest diverse bioactivities, including antitumor, immunomodulatory, antifungal, HIV-1 reverse transcriptase inhibitory, and anti-insect activities [188]. Moreover, they can also inhibit fungal growth and induce the release of histamines [186]. Some proteins exhibit highly potent antiproliferative and anti-metastasis activity toward some tumor cell lines (human leukemic T cells, hepatoma Hep G2 cells, and breast cancer MCF7 cells) [185]. A lectin isolated from Ganoderma applanatum was shown to have antiproliferative activity in HT-29 colon cancer cells [189]. The in vivo immunomodulatory effects of lectin isolated from A. bisporus was also studied [190]. Lectin from P. ostreatus (POL) stimulated an immune response and has been considered as a potential therapeutic approach to break HBV tolerance [191]. It has also been shown to act as a food-intake-suppressing substance, which can help in weight reduction [192]. A lectin-like protein of unknown function designated as a light subunit of mushroom A. bisporus tyrosinase (LSMT) showed inhibition of cell growth of breast cancer cells and light stimulation of cell proliferation of macrophage cells. These homologous proteins display the ability to penetrate the intestinal epithelial cell monolayer, and are adequate for oral administration. Just like other lectins it can be developed as a drug carrier and anticancer treatment [193].

Ergothioneine is an amino acid that is found in some mushrooms, such as A. bisporus [194] and Pleurotus citrinopileatus [195] (Figure 2). It is a thiourea derivative of histidine, containing a sulfur atom bonded to the 2-position on the imidazole ring [196]. Early studies showed that humans are unable to synthesize this compound, and its presence in the blood is mostly dependent on diet [194]. Ergothioneine demonstrated antioxidant and cytoprotective capacities in vitro $[194,196,197]$. These functions may highlight therapeutic benefits against numerous conditions in humans. Cheah \& Halliwell [198] proposed that ergothioneine could be used as a therapeutic to reduce the severity and mortality of COVID-19.

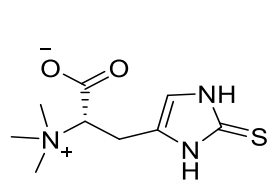

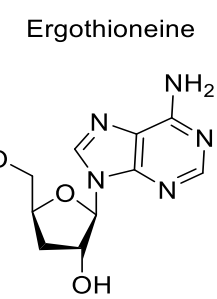

Cordycepin<smiles>CCC(C)C(=O)OC1CC(C)C=C2C=CC(C)C(CCC3CC(O)CC(=O)O3)C21</smiles>

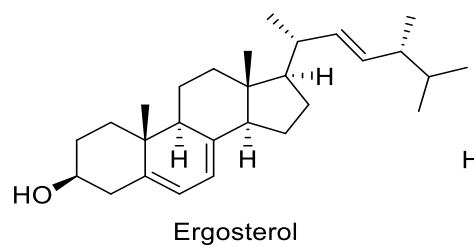<smiles>N[C@@H](CCC(=O)NNc1ccc(CO)cc1)C(=O)O</smiles>

Agaritine<smiles>CC(C)C1=C2C3=CC=C(C=O)C[C@H](O[C@@H]4OC[C@@H](O)[C@H](O)[C@H]4O)[C@]3(C)CC[C@]2(C)CC1</smiles>

Erinacine A

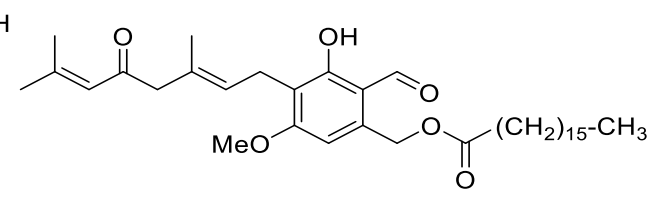

Hericenone D

Figure 2. Chemical structures of other bioactive compounds found in macrofungi. 
Flammulin is a ribosome-inactivating protein (RIP) from the fruiting bodies of F. velutipes. It has a molecular weight of $40 \mathrm{kDa}$, and is capable of inhibiting cell-free translation in a rabbit reticulocyte lysate system, with an $\mathrm{IC}_{50}$ of $0.25 \mathrm{nM}$ [199]. Flammulin is an antitumor substance [200], with inhibitory effects on the proliferation of sarcoma 180 and Ehrlich ascites tumors [201,202]. This protein also affected immune reactions and had positive effects on the therapy of various types of cancer. Hemagglutinin is another promising bioactive compound isolated from the fruiting bodies of F. velutipes. It can stimulate [3H-methyl] thymidine uptake by mouse splenocytes and inhibits proliferation of leukemia L1210 cells [203].

\subsection{Fats}

The amount of fats in mushroom fruiting bodies is low compared to carbohydrates and proteins. The fats present in mushrooms are mostly unsaturated fatty acids. Mushrooms are rich in linolenic acid, which is an essential fatty acid [204]. Other lipids, such as tocopherols, are essential fatty acids that take part in a wide range of physiological functions. They have high antioxidant activities which help in protecting the body against degenerative malfunctions, cancer, and cardiovascular diseases [5,204,205]. Some lipid components, including fatty acids, fatty acid esters, and sterols, were identified from the ethyl acetate extract of Cordyceps militaris. This extract at $10 \mu \mathrm{g} / \mathrm{mL}$ concentration was able to reduce the NO production in Bv2 cells by $85 \%$ via activation of NRF2 and NF- $\kappa$ B transcription. Moreover, it downregulated inflammatory genes, iNOS and COX-2, and upregulated anti-inflammatory genes, HO-1 and NQO-1 [206], which could be very useful in treating neurodegenerative diseases [207]. The lipids extracted from the ethyl acetate fraction of Pleurotus giganteus also showed antifungal activity by significantly inhibiting the growth of all the Candida species tested in the study by Phan et al. [208].

Ergosterol, also produced in mushrooms, has been shown to have antioxidant properties [209], which helps prevent cardiovascular diseases [210] (Figure 2). Ergosterol (ergosta-5,7,22-trien-3 $\beta$-ol) is a sterol found in cell membranes of fungi and protozoa that plays an important role in fundamental biological processes, such as signal transduction, cellular sorting, cytoskeleton reorganization, asymmetric growth, and the response to infectious diseases [211]. This compound is necessary for the survival of many fungi and protozoa. The enzymes that synthesize ergosterol have become important targets for antifungal drug discovery [212]. Ergosterol is a steroid precursor of vitamin D2. In human nutrition, exposure to small amounts of ultraviolet light is required for the activation of vitamin D. Among the cultivated mushrooms, the Pleurotus species have been shown to have relatively higher concentrations of ergosterol, with better conversion to vitamin D2 [213,214]. Extracts from organically produced L. edodes also contain the high content of ergosterol [215]. Agarol is an ergosterol derived from Agaricus blazei which has anticancer properties, inhibiting the proliferation of A549, MKN45, HSC-3, and HSC-4 human carcinoma cell lines [216].

\subsection{Phenolic Compounds}

Phenolic compounds are secondary metabolites possessing an aromatic ring with one or more hydroxyl groups, and their structure can be that of a simple phenolic molecule or a complex polymer. Phenolic compounds in mushrooms are excellent antioxidants and synergists, while not being mutagenic. They also exhibit a wide range of physiological properties, such as antiallergenic, antiatherogenic, anti-inflammatory, antimicrobial, antithrombotic, cardioprotective, and vasodilator effects [5]. Phenolic compounds are well documented for their antioxidant activity as free radical scavengers, singlet oxygen quenchers, or metal ion chelators [204,205]. Thus, they provide protection against several degenerative disorders, including brain dysfunction, cancer, and cardiovascular diseases [5]. Phenolic compounds reported from mushrooms include protocatechuic, p-hydroxybenzoic, p-coumaric, and cinnamic acids [204]. 


\subsection{Vitamins}

Vitamins are essential nutrients in the human body. They play an important role in bodily functions, such as metabolism, immunity, and digestion. Mushrooms are a good source of vitamins, especially of group B, namely thiamine (vitamin B1), riboflavin (vitamin B2), pyridoxine (vitamin B6), pantothenic acid (vitamin B5), nicotinic acid/niacin and its amide named nicotinamide (vitamin B3), folic acid (vitamin B9), and cobalamin (vitamin B12) $[217,218]$. Other vitamins, such as biotin (vitamin B8), tocopherol (vitamin E), and ergosterol, a precursor of vitamin D2, are also present [217]. Mushroom species such as Boletus edulis have a high group B content [219]. Pleurotus ostreatus contains high amounts of folacine (vitamin B9), and vitamins B1 and B3 [218]. Lentinula edodes and Boletus edulis have a high content of vitamin D [218]. The most common vitamin D in mushrooms is vitamin D2, which can also be found in vegetables and, thus, can be used as food supplements for vegetarians. Vitamin D4, 22-dihydroergocalciferol, can also be found in some mushrooms (agarics, morel, chanterelle) [220], but in small amounts [221]. Vitamin D has been suggested to have some therapeutic applications in the treatment of several diseases. In recent years, several clinical trials have been performed to investigate the therapeutic value of vitamin $\mathrm{D}$ in hyperproliferative diseases, secondary hyperparathyroidism, multiple sclerosis, rheumatoid arthritis, Crohn disease, type I diabetes, systemic lupus erythematosus, and various malignancies [222,223]. Vitamin D also helps in maintaining a healthy immune system by signaling the immune cells and promoting their ability to metabolize 25(OH)D3 into its active form 1,25(OH)2D3 [224].

\subsection{Other Bioactive Compounds}

Agaritine is an aromatic hydrazine-derivative compound identified in Agaricus species (Figure 2). It belongs to the IARC Group 3 carcinogens [225]. This compound is said to be toxic to animals and humans in large doses, but the review of Roupas et al. [225] stated that consumption of cultivated A. bisporus mushrooms poses no known toxicological risk to healthy humans. This compound could potentially be developed into antiviral drugs [226,227]. It also exhibits antitumor effects against leukemic cells in vitro [228].

Cordycepin, or 3'-deoxyadenosine, is the most vital bioactive compound produced by Cordyceps (Figure 2). The structure of cordycepin consists of a purine molecule attached to one ribose sugar moiety [229]. The bioactivities demonstrated by this compound are antiaging, antiarthritic, anticancer, antidiabetic, antifungal, antihyperlipidemia, antiinflammatory, antimalarial, anti-osteoporotic, antioxidant, antiviral, hepato-protective, hypo-sexuality, immunomodulatory, weight-regulating, and many more nutraceutical and pharmaceutical applications in cardiovascular diseases, as well as general applications for maintaining good health [229-234]. Cordycepin isolated from Cordyceps militaris significantly inhibited the growth of MCF-7 human breast cancer cells with an $\mathrm{IC}_{50}$ value of $9.58 \mu \mathrm{M}[235]$.

Erinacines isolated from the cultured mycelia of $H$. erinaceus belong to the group of cyathin diterpenoids (erinacines A-K, P, and Q), which have been shown to have an enhancing effect on nerve growth factor synthesis in vitro $[236,237]$. Erinacines show biological activities, including acting as stimulators of nerve growth factor (NGF) synthesis, suggesting it could be useful as a treatment for neurodegenerative disorders and peripheral neuropathy [238]. Erinacine A-enriched H. erinaceus mycelial extract was previously demonstrated to have antidepressant like effects in mice, activating the BDNF/TrkB/PI3K/Akt/GSK-3 $\beta$ pathways and blocking NF- $\mathrm{KB}$ mediated signaling [239]. Erinacine A also inhibited the growth of DLD-1 colorectal cancer cells [240] (Figure 2). Three capsules of $350 \mathrm{mg} / \mathrm{g}$ erinacine A-enriched H. erinaceus (EAHE) treatment for 49 weeks demonstrated higher positive results in patients with mild $\mathrm{AD}$ and achieved a better contrast sensitivity compared to the placebo group, suggesting that EAHE is safe, well tolerated, and may be important in achieving neurocognitive benefits [241].

Ganoderic acids are triterpenoids used as adjuvants in therapies and other medications. They can be used to treat hepatitis, fatigue syndrome, and prostate cancer [242]. Ganoderic 
acid also showed neuroprotective effects against the STZ-induced type I diabetes mellitus mouse model, with prebiotic effects on the gut microbiota allowing the growth of diabetes resistant bacteria [243]. It also worked as an antioxidant, exhibiting downregulation in Notch-1 mRNA expression and inhibiting proliferation, viability, and ROS activity in IMR-32 cells, thus can be potentially used to treat neuroblastomas [244].

Hericenones are also isolated from Hericium erinaceus. Just like erinacines, hericecones also promote NGF synthesis, wherein hericenone D (Figure 2) has almost the same degree of activity as the potent stimulator epinephrine [238]. They have been found to have antiobesity properties which decrease fat cell number and improve body fat condition [245]. They also have strong antiplatelet activity [246]. It is important to note that hericenones have only been reported in the fruiting bodies of H. erinaceus, while erinacines have been found only in mycelium [238].

Lovastatin is a lactone metabolite isolated from the fungus Aspergillus terreus and also found in some mushrooms $[247,248]$ (Figure 2). It has cholesterol-lowering, potential antineoplastic, and antitumor activities [248-250]. In comparison with other adjuvants, lovastatin showed more efficacious results than gemfibrozil in the reduction of total cholesterol $(23 \% \mathrm{v} 9 \%, p<0.001)$ and low-density lipoprotein (LDL) cholesterol $(28 \% \mathrm{v} 2 \%$, $p<0.001)$ [251].

\section{Macrofungi Nutraceutical Market Overview}

In the last decade, nutraceuticals and dietary supplements have increased in market value, owing to their role in the prevention of health risks and improving the health quality of human beings. The industry of nutraceuticals first emerged in the 1990s [252]. The nutraceutical market became more competitive when many major pharmaceutical and food companies ventured into the nutraceutical arena. According to the study conducted by PMMI Business Intelligence [253], the global nutraceutical market was worth approximately USD 241 billion in the year 2019, and is expected to bloom up to USD 373 billion by 2025 (Figure 3). The projection is that it will therefore grow at a 7.5\% compound annual growth rate (CAGR) [254].

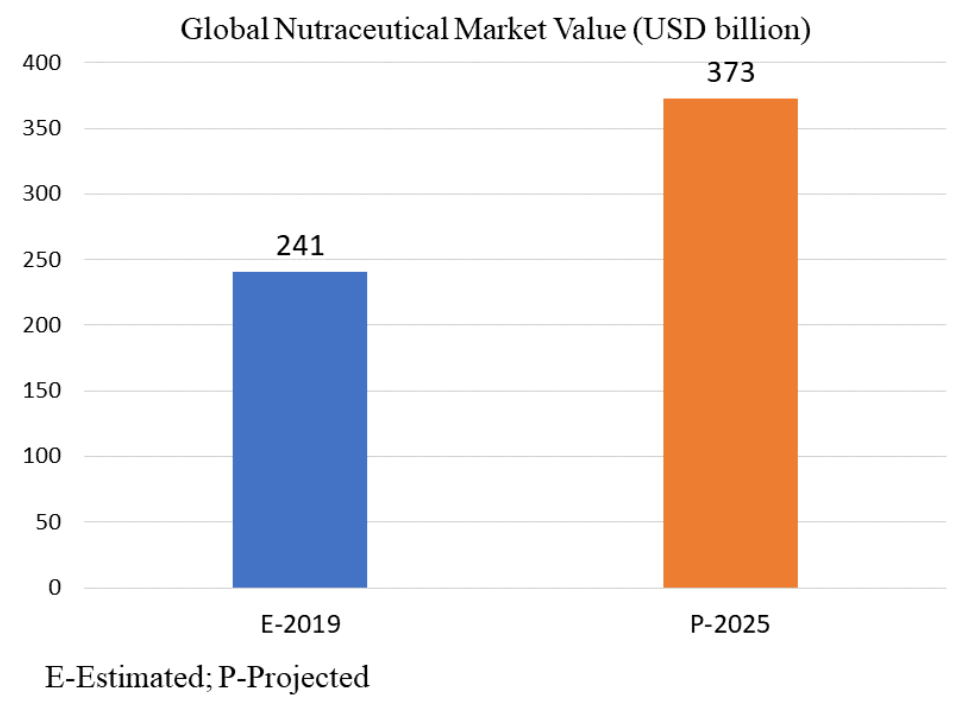

Figure 3. Global market value of nutraceuticals estimated in 2019 and projected in 2025 by PMMI Business Intelligence [253].

Medicinal mushrooms are joining the nutraceutical market. The health-promoting benefits of consuming mushrooms have been a driving force in their increased market value. The global edible mushrooms market is forecasted to grow at a high CAGR of $7.9 \%$ during 2020-2027 [255]. Edible mushrooms had a global market value of USD 42.42 billion in the year 2018, USD 45.3 billion in 2020, and are forecasted to increase up to USD 62.19 billion 
in 2023, and USD 72.5 billion by 2027, growing at a CAGR of 7\% over the analysis period 2020-2027 [13] (Figure 4). According to Market Data Forecast [256], the market value of edible mushrooms for Europe in 2018 was USD 13.71 billion, while Asia Pacific had a market value around USD 12.79 billion. It is expected to rise to USD 21.67 billion for Europe and USD 20.18 billion for Asia Pacific in 2023.

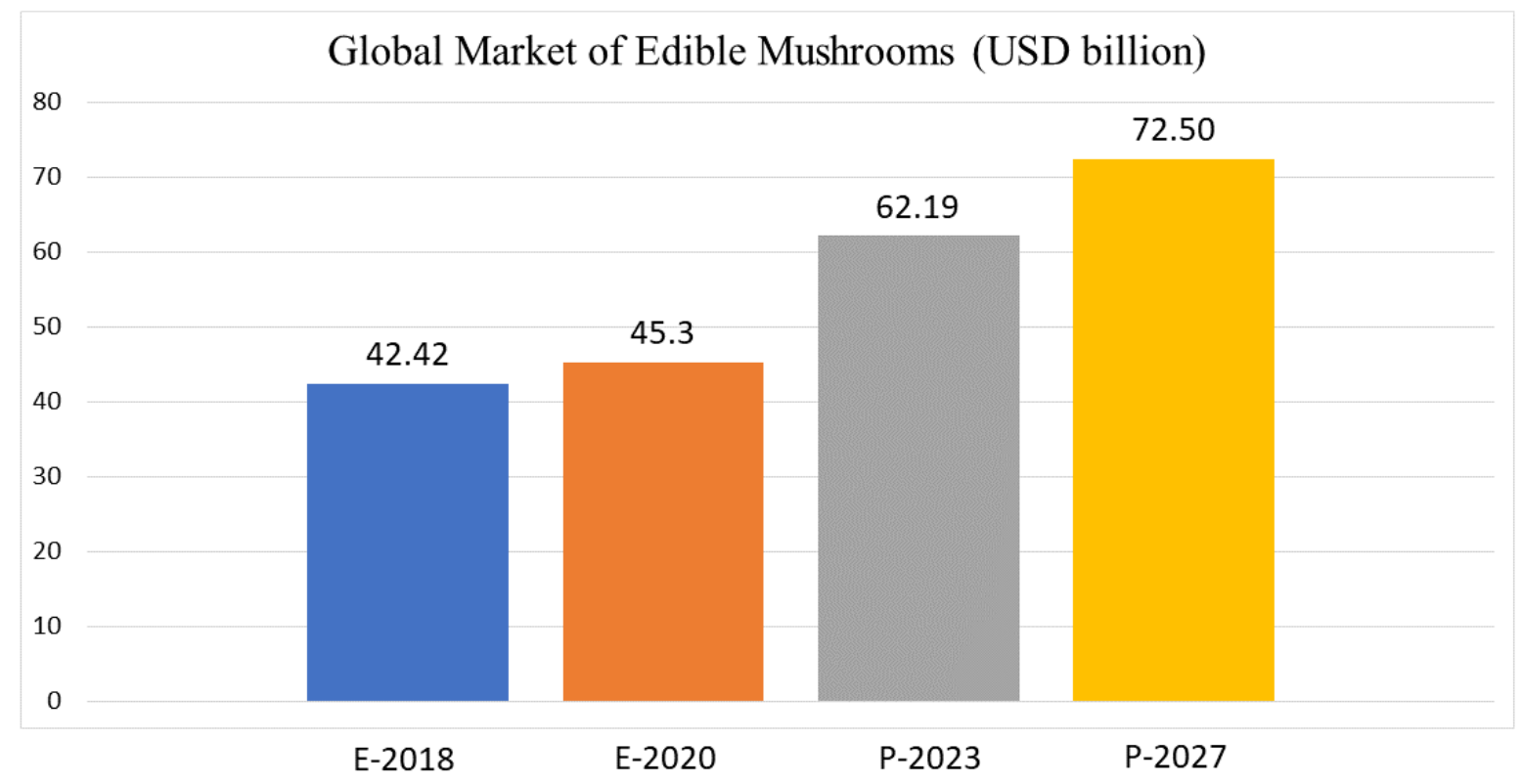

E-Estimated; P-Projected

Figure 4. Global annual market revenue (USD billion) of edible mushrooms estimated and projected by Research and Markets [13].

The market report of Technavio [10] projected that the medicinal mushroom market size will increase by USD 13.88 billion from 2018-2022 based on the analysis of the marketbased products of Reishi mushroom, Chaga mushroom, and other medicinal mushrooms in the Americas, Asia-Pacific (APAC), Europe, and the Middle East and Africa (EMEA). Moreover, the growth of the population of people adopting a vegan diet will also likely result in an increase of the medicinal mushroom market CAGR to over 9\% during 20182022 [10]. Mushroom nutraceuticals are often prepared as dietary supplements. The global dietary supplements market size is estimated to be valued at USD 136.2 billion in 2020 and projected to reach USD 204.7 billion by 2026, with a CAGR of $7.0 \%$ during the forecast period [257]. Changes in lifestyle, dietary habits, and positive outlook towards sport nutrition are the major factors driving the demand for dietary supplements.

Several pharmaceuticals (coriolan, krestin, lentinan, schizophyllan, etc.) formulated from medicinal mushrooms are already available in the world market [258]. The market value of glucans is more than USD 200 million, and expected to grow rapidly in medical, food, and cosmetic industries [259]. The global Ophiocordyceps sinensis (as Cordyceps sinensis) and Cordyceps militaris extract (cordycepins) market size was valued at USD 473.4 million in 2018, with a CAGR of $10.4 \%$ during the forecast period (2018-2026), and is predicted to surpass USD 1 billion by 2026 [260]. Asia Pacific (mainly China) is considered as the main producer of cordycepin from O. sinensis and C. militaris [229].

The market for lentinan is also expected to rise, with the global market valued at USD 10 million in 2020. It is predicted it will reach USD 12 million by the end of 2027, growing at a CAGR of 3.3\% during the forecast period 2021-2027 [261].

Lovastatin and other statins are currently witnessing a stable market growth. According to Research and Markets [262], the increasing incidence of hypercholesterolemia among the geriatric population worldwide is among the key factors driving the growth of the 
market. The increasing consumer preference for more affordable over-the-counter (OTC) drugs is also another factor contributing to the market growth of statins.

\section{Future Perspective}

Nutraceuticals are of great importance for maintaining human health; thus, the market value for this industry is surging. Macrofungi produce many important bioactive compounds, with polysaccharides as the most promising nutraceuticals, having anticancer, antibacterial, antidiabetic, antiviral, immunoregulatory, and immunostimulatory properties, as well as hepato- and kidney-protective effects, antiaging activity, and many more bioactivities. Moreover, bioactive proteins, fats, and vitamins also present promising nutraceutical applications.

The growing demand for functional food and dietary supplements will cause a surge in product development and innovation, resulting in the increased market value of nutraceuticals, as projected by some research market studies. The diverse and unique marketing strategies by key players will also enable the health industry to grow in market value in the coming years [263]. Moreover, investment in research and development (R\&D) to verify and confirm health claims, find innovative approaches, and market research are the driving forces for the success of the nutraceutical industry.

The consumption of medicinal mushrooms as a component of functional food and dietary supplementation is expected to have a remarkable upsurge in the future. The converging trends and popularity of eastern herbal medicines, natural/organic food product preference, gut-healthy products, and the positive outlook towards sport nutrition are supporting the growth in the medicinal mushroom market. The major drawback for medicinal mushrooms would be the taste, in which the medicinal mushroom industry spends extra cost in order to mask the bitter or mud-like tastes [264].

All the medicinal claims relating to medicinal mushrooms should be backed up by scientific studies, since the trust and confidence of customers are greatly influenced by the opinion of scientific communities. The popularity of medicinal mushrooms is directly related to research and development. The key strategies to success in mushroom nutraceuticals are consumer awareness, innovation, and educational marketing. According to Persistence Market Research [264], these products can get high-end consumers by marketing them through fashion magazines, spas, and other beauty supplement stores. There is also an expected rise of market value in developing countries where retail stores are stacked with functional food and beverages. It was also suggested that collaborations with various herbal supplement distributing chains would further increase the growth of mushroom nutraceuticals.

Only a handful of mushrooms have been considered economically important as nutraceuticals, namely Agaricus bisporus (button mushroom), Ganoderma lingzhi/G. sichuanense (Reishi), Grifola frondosa (maitake), Hericium erinaceus (lion's mane), Lentinula edodes (shiitake), Ophiocordyceps sinensis (cordyceps), and Trametes versicolor (turkey tail). However, many other medicinal mushrooms are very promising, such as Auricularia auricular-judae, Calocybe indica, Pleurotus spp., Schizophyllum commune, and Volvariella volvacea. Opportunities for exploring mushrooms are enormous, but proper identification is very important, and further studies on the toxicity are necessary since numerous mushrooms are toxic and can be fatal when consumed.

The bioactive compounds from macrofungi hold a promise for future innovations for drug development, and as supplements to combat and prevent human diseases. However, the high price and low public awareness of medicinal mushrooms have become market limitations. In addition, the lack of quality control is also a major area of concern for mushroom nutraceuticals. Further research regarding the nutraceutical applications of macrofungi should be conducted to further validate their efficacy and safety.

Author Contributions: Conceptualization, A.G.N., S.R., N.T., and K.D.H.; writing-original draft preparation, A.G.N., S.R., and N.T.; writing-review and editing, S.R., K.D.H., and O.R.; chemical structures preparation, W.J.; investigation, K.D.H., A.G.N., S.R., and O.R.; visualization, N.T. and 
S.L.; resources, N.T., S.L., and W.J.; data curation, A.G.N., S.R., and O.R. All authors have read and agreed to the published version of the manuscript.

Funding: This review is supported by Thailand Science Research and Innovation grant "Macrofungi diversity research from the Lancang-Mekong Watershed and surrounding areas" (Grant No. DBG6280009) and Thailand Research Fund grant "Study of saprobic Agaricales in Thailand to find new industrial mushroom products" (Grant No. DBG6180015).

Institutional Review Board Statement: Not applicable.

Informed Consent Statement: Not applicable.

Data Availability Statement: Not applicable.

Acknowledgments: K.D. Hyde thanks Chiang Mai University for the award of Visiting Professor. We also would like to thank Rawiwan Charoensup for providing materials needed. Adam Kaplan is thanked for editing the English in the paper.

Conflicts of Interest: The authors declare no conflict of interest.

\section{References}

1. Chang, S.T.; Wasser, S.P. Current and future research trends in agricultural and biomedical applications of medicinal mushrooms and mushroom products (review). Int. J. Med. Mushrooms 2018, 20, 1121-1133. [CrossRef] [PubMed]

2. Lu, H.; Lou, H.; Hu, J.; Liu, Z.; Chen, Q. Macrofungi: A review of cultivation strategies, bioactivity, and application of mushrooms. Compr. Rev. Food Sci. Food Saf. 2020, 19, 2333-2356. [CrossRef]

3. Willis, K.J. State of the World's Fungi 2018. Available online: https://stateoftheworldsfungi.org/ (accessed on 18 March 2021).

4. Feeney, M.J.; Dwyer, J.; Hasler-Lewis, C.M.; Milner, J.A.; Noakes, M.; Rowe, S.; Wach, M.; Beelman, R.B.; Caldwell, J.; Cantorna, M.T.; et al. Mushrooms and health summit proceedings. J. Nutr. 2014, 144, 1128S-1136S. [CrossRef] [PubMed]

5. Valverde, M.E.; Hernández-Pérez, T.; Paredes-López, O. Edible mushrooms: Improving human health and promoting quality life. Int. J. Microbiol. 2015, 2015, 1-14. [CrossRef]

6. Samsudin, N.I.P.; Abdullah, N. Edible mushrooms from Malaysia; a literature review on their nutritional and medicinal properties. Int. Food Res. J. 2019, 26, 11-31.

7. Huang, J.; Ou, Y.; Yew, T.W.D.; Liu, J.; Leng, B.; Lin, Z.; Su, Y.; Zhuang, Y.; Lin, J.; Li, X.; et al. Hepatoprotective effects of polysaccharide isolated from Agaricus bisporus industrial wastewater against CCl4-induced hepatic injury in mice. Int. J. Biol. Macromol. 2016, 82, 678-686. [CrossRef]

8. Yang, W.; Wang, L.; Hu, Q. Development situation on processing technology and product innovation of edible mushroom in China. J. Food Sci. Technol. 2019, 37, 13-18. [CrossRef]

9. Agrawal, S.; Jha, K.N. Medicinal mushrooms. J. Crit. Rev. 2020, 7, 1401-1407. [CrossRef]

10. Technavio Medicinal Mushrooms Market 2018-2022. Available online: https://www.technavio.com/report/global-medicinalmushrooms-market-analysis-share-2018\#: \{\}:text=The \%20medicinal $\% 20$ mushrooms $\% 20$ market $\% 20$ size, $\% 2$ C $\% 20 \mathrm{APAC} \% 2 \mathrm{C} \%$ 20and\%20EMEA (accessed on 10 March 2021).

11. Shamtsyan, M. Bioactive compounds in mushrooms. In Encyclopedia of Biotechnology in Agriculture and Food; Heldman, D., Wheeler, M., Hoover, D., Eds.; CRC Press: Boca Raton, FL, USA, 2010; pp. 76-81.

12. Raman, J.; Lee, S.-K.; Im, J.-H.; Oh, M.-J.; Oh, Y.-L.; Jang, K.-Y. Current prospects of mushroom production and industrial growth in India. J. Mushrooms 2018, 4, 239-249. [CrossRef]

13. Research and Markets Global edible Mushrooms Market-Industry Trends, Opportunities and Forecasts to 2023. Available online: https: / / www.researchandmarkets.com/reports / 4451952/global-edible-mushrooms-market-industry-trends (accessed on 20 March 2021).

14. Barros, L.; Cruz, T.; Baptista, P.; Estevinho, L.M.; Ferreira, I.C.F.R. Wild and commercial mushrooms as source of nutrients and nutraceuticals. Food Chem. Toxicol. 2008, 46, 2742-2747. [CrossRef] [PubMed]

15. Mollet, B.; Rowland, I. Functional foods: At the frontier between food and pharma. Curr. Opin. Biotechnol. 2002, 13, 483-485. [CrossRef]

16. Sobieralski, K.; Siwulski, M.; Lisiecka, J.; Jedryczka, M.; Sas-Golak, I.; Fruzyńska-Jóźwiak, D. Fungi-derived $\beta$-glucans as a component of functional food. Acta Sci. Pol. Hortorum Cultus 2012, 11, 111-128.

17. Hyde, K.D.; Xu, J.; Rapior, S.; Jeewon, R.; Lumyong, S.; Niego, A.G.T.; Abeywickrama, P.D.; Aluthmuhandiram, J.V.S.; Brahamanage, R.S.; Brooks, S.; et al. The amazing potential of fungi: 50 ways we can exploit fungi industrially. Fungal Divers. 2019, 97, 1-136. [CrossRef]

18. De Silva, D.D.; Rapior, S.; Fons, F.; Bahkali, A.H.; Hyde, K.D. Medicinal mushrooms in supportive cancer therapies: An approach to anti-cancer effects and putative mechanisms of action. Fungal Divers. 2012, 55, 1-35. [CrossRef]

19. Badalyan, S.M.; Rapior, S. The neurotrophic and neuroprotective potential of macrofungi. In Medicinal Herbs and Fungi; Springer Nature Singapore: Singapore, 2021; pp. 37-77. 
20. De Silva, D.D.; Rapior, S.; Hyde, K.D.; Bahkali, A.H. Medicinal mushrooms in prevention and control of diabetes mellitus. Fungal Divers. 2012, 56, 1-29. [CrossRef]

21. Rathore, H.; Prasad, S.; Sharma, S. Mushroom nutraceuticals for improved nutrition and better human health: A review. PharmaNutrition 2017, 5, 35-46. [CrossRef]

22. Varghese, R.; Dalvi, Y.B.; Lamrood, P.Y.; Shinde, B.P.; Nair, C.K.K. Historical and current perspectives on therapeutic potential of higher basidiomycetes: An overview. 3 Biotech 2019, 9, 362. [CrossRef] [PubMed]

23. Reis, F.S.; Barros, L.; Martins, A.; Ferreira, I.C.F.R. Chemical composition and nutritional value of the most widely appreciated cultivated mushrooms: An inter-species comparative study. Food Chem. Toxicol. 2012, 50, 191-197. [CrossRef]

24. Ghosh, K. A review on edible straw mushrooms: A source of high nutritional supplement, biologically active diverse structural polysaccharides. J. Sci. Res. 2020, 64, 295-304. [CrossRef]

25. Semwal, K.; Lemma, H.; Dhyani, A.; Equar, G.; Amhare, S. Mushroom: Nature's treasure in Ethiopia. Momona Ethiop. J. Sci. 2014, 6, 138. [CrossRef]

26. Chang, S.T.; Wasser, S.P. The role of culinary-medicinal mushrooms on human welfare with a pyramid model for human health. Int. J. Med. Mushrooms 2012, 14, 95-134. [CrossRef]

27. Govorushko, S.; Rezaee, R.; Dumanov, J.; Tsatsakis, A. Poisoning associated with the use of mushrooms: A review of the global pattern and main characteristics. Food Chem. Toxicol. 2019, 128, 267-279. [CrossRef] [PubMed]

28. Zeb, M.; Lee, C.H. Medicinal properties and bioactive compounds from wild mushrooms native to North America. Molecules 2021, 26, 251. [CrossRef] [PubMed]

29. Thongbai, B.; Rapior, S.; Hyde, K.D.; Wittstein, K.; Stadler, M. Hericium erinaceus, an amazing medicinal mushroom. Mycol. Prog. 2015, 14, 91. [CrossRef]

30. Öztürk, M.; Tel-Çayan, G.; Muhammad, A.; Terzioğlu, P.; Duru, M.E. Mushrooms. In Studies in Natural Products Chemistry; Elsevier: Amsterdam, The Netherlands, 2015; Volume 45, pp. 363-456.

31. Cheung, P.C.K. Mini-review on edible mushrooms as source of dietary fiber: Preparation and health benefits. Food Sci. Hum. Wellness 2013, 2, 162-166. [CrossRef]

32. Temesgen, T. Application of mushroom as food and medicine. Adv. Biotechnol. Microbiol. 2018, 11, 555817. [CrossRef]

33. Khan, M.A.; Tania, M. Nutritional and medicinal importance of Pleurotus mushrooms: An overview. Food Rev. Int. 2012, 28, 313-329. [CrossRef]

34. Wannet, W.J.B.; Hermans, J.H.M.; van der Drift, C.; Op den Camp, H.J.M. HPLC detection of soluble carbohydrates involved in mannitol and trehalose metabolism in the edible mushroom Agaricus bisporus. J. Agric. Food Chem. 2000, 48, $287-291$. [CrossRef] [PubMed]

35. Food Data Central Mushroom Raw. Available online: https://fdc.nal.usda.gov/fdc-app.html\#/food-details/169251/nutrients (accessed on 18 March 2021).

36. Malinowska, E.; Szefer, P.; Falandysz, J. Metals bioaccumulation by bay bolete, Xerocomus badius, from selected sites in Poland. Food Chem. 2004, 84, 405-416. [CrossRef]

37. Rudawska, M.; Leski, T. Macro- and microelement contents in fruiting bodies of wild mushrooms from the Notecka forest in west-central Poland. Food Chem. 2005, 92, 499-506. [CrossRef]

38. Goyal, R.; Grewal, R.B.; Goyal, R.K. Nutritional attributes of Agaricus bisporus and Pleurotus sajor caju mushrooms. Nutr. Health 2006, 18, 179-184. [CrossRef]

39. Cohen, N.; Cohen, J.; Asatiani, M.D.; Varshney, V.K.; Yu, H.-T.; Yang, Y.-C.; Li, Y.-H.; Mau, J.-L.; Wasser, S.P. Chemical composition and nutritional and medicinal value of fruit bodies and submerged cultured mycelia of culinary-medicinal higher basidiomycetes mushrooms. Int. J. Med. Mushrooms 2014, 16, 273-291. [CrossRef]

40. Pereira, E.; Barros, L.; Martins, A.; Ferreira, I.C.F.R. Towards chemical and nutritional inventory of Portuguese wild edible mushrooms in different habitats. Food Chem. 2012, 130. [CrossRef]

41. Ouzouni, P.K.; Petridis, D.; Koller, W.-D.; Riganakos, K.A. Nutritional value and metal content of wild edible mushrooms collected from West Macedonia and Epirus, Greece. Food Chem. 2009, 115, 1575-1580. [CrossRef]

42. Vaz, J.A.; Barros, L.; Martins, A.; Santos-Buelga, C.; Vasconcelos, M.H.; Ferreira, I.C.F.R. Chemical composition of wild edible mushrooms and antioxidant properties of their water soluble polysaccharidic and ethanolic fractions. Food Chem. 2011, 126, 610-616. [CrossRef]

43. Ao, T.; Deb, C.R. Nutritional and antioxidant potential of some wild edible mushrooms of Nagaland, India. J. Food Sci. Technol. 2019, 56, 1084-1089. [CrossRef]

44. Bandara, A.R.; Karunarathna, S.C.; Mortimer, P.E.; Hyde, K.D.; Khan, S.; Kakumyan, P.; Xu, J. First successful domestication and determination of nutritional and antioxidant properties of the red ear mushroom Auricularia thailandica (Auriculariales, Basidiomycota). Mycol. Prog. 2017, 16, 1029-1039. [CrossRef]

45. Heleno, S.A.; Barros, L.; Sousa, M.J.; Martins, A.; Santos-Buelga, C.; Ferreira, I.C.F.R. Targeted metabolites analysis in wild Boletus species. LWT Food Sci. Technol. 2011, 44, 1343-1348. [CrossRef]

46. Grangeia, C.; Heleno, S.A.; Barros, L.; Martins, A.; Ferreira, I.C.F.R. Effects of trophism on nutritional and nutraceutical potential of wild edible mushrooms. Food Res. Int. 2011, 44, 1029-1035. [CrossRef] 
47. Vieira, V.; Fernandes, Â.; Barros, L.; Glamočlija, J.; Ćirić, A.; Stojković, D.; Martins, A.; Soković, M.; Ferreira, I.C.F.R. Wild Morchella conica Pers. from different origins: A comparative study of nutritional and bioactive properties. J. Sci. Food Agric. 2016, 96, 90-98. [CrossRef] [PubMed]

48. Télessy, I.G. Nutraceuticals. In The Role of Functional Food Security in Global Health; Singh, R.B., Watson, R.R., Takahashi, T., Eds.; Elsevier: Amsterdam, The Netherlands, 2019; pp. 409-421. ISBN 978-0-12-813148-0.

49. Kalra, E.K. Nutraceutical-definition and introduction. AAPS PharmSci 2003, 5, 27-28. [CrossRef]

50. Daliu, P.; Santini, A.; Novellino, E. A decade of nutraceutical patents: Where are we now in 2018? Expert Opin. Ther. Pat. 2018, 28, 875-882. [CrossRef] [PubMed]

51. Dudeja, P.; Gupta, R.K. Nutraceuticals. In Food Safety in the 21st Century; Dudeja, P., Kumar, R., Amarjeet, G., Minhas, S., Eds.; Elsevier: Amsterdam, The Netherlands, 2017; pp. 491-496. ISBN 9780128017739.

52. Das, L.; Bhaumik, E.; Raychaudhuri, U.; Chakraborty, R. Role of nutraceuticals in human health. J. Food Sci. Technol. 2012, 49, 173-183. [CrossRef] [PubMed]

53. Royse, D.J.; Baars, J.; Tan, Q. Current overview of mushroom production in the world. In Edible and Medicinal Mushrooms; John Wiley \& Sons, Ltd.: Chichester, UK, 2017; pp. 5-13.

54. Chang, S.T.; Buswell, J.A. Mushroom nutriceuticals. World J. Microbiol. Biotechnol. 1996, 12, 473-476. [CrossRef] [PubMed]

55. Patel, S.; Goyal, A. Recent developments in mushrooms as anti-cancer therapeutics: A review. 3 Biotech 2012, 2, 1-15. [CrossRef]

56. Olawuyi, I.F.; Lee, W.Y. Quality and antioxidant properties of functional rice muffins enriched with shiitake mushroom and carrot pomace. Int. J. Food Sci. Technol. 2019, 54, 2321-2328. [CrossRef]

57. Kumar, K. Role of edible mushroom as functional foods: A review. South Asian J. Food Technol. Environ. 2015, 1, 211-218. [CrossRef]

58. Raghavendra, V.B.; Venkitasamy, C.; Pan, Z.; Nayak, C. Functional foods from mushroom. In Microbial Functional Foods and Nutraceuticals; John Wiley \& Sons, Ltd.: Chichester, UK, 2017; pp. 65-91.

59. Wu, F.; Zhou, L.-W.; Yang, Z.-L.; Bau, T.; Li, T.-H.; Dai, Y.-C. Resource diversity of Chinese macrofungi: Edible, medicinal and poisonous species. Fungal Divers. 2019, 98, 1-76. [CrossRef]

60. Meng, X.; Liang, H.; Luo, L. Antitumor polysaccharides from mushrooms: A review on the structural characteristics, antitumor mechanisms and immunomodulating activities. Carbohydr. Res. 2016, 424, 30-41. [CrossRef] [PubMed]

61. Hetland, G.; Tangen, J.-M.; Mahmood, F.; Mirlashari, M.R.; Nissen-Meyer, L.S.H.; Nentwich, I.; Therkelsen, S.P.; Tjønnfjord, G.E.; Johnson, E. Antitumor, anti-inflammatory and antiallergic effects of Agaricus blazei mushroom extract and the related medicinal basidiomycetes mushrooms, Hericium erinaceus and Grifola frondosa: A review of preclinical and clinical studies. Nutrients 2020, 12, 1339. [CrossRef]

62. Badalyan, S.; Badalyan, S.; Barkhudaryan, A. The cardioprotective properties of Agaricomycetes mushrooms growing in the territory of Armenia (review). Int. J. Med. Mushrooms 2021, 23, 21-31. [CrossRef]

63. Wasser, S.P. Current findings, future trends, and unsolved problems in studies of medicinal mushrooms. Appl. Microbiol. Biotechnol. 2011, 89, 1323-1332. [CrossRef]

64. Jeff, I.B.; Fan, E.; Tian, M.; Song, C.; Yan, J.; Zhou, Y. In vivo anticancer and immunomodulating activities of mannogalactoglucantype polysaccharides from Lentinus edodes (Berkeley) Singer. Cent. Eur. J. Immunol. 2016, 1, 47-53. [CrossRef]

65. Rubel, R.; Santa, H.S.D.; dos Santos, L.F.; Fernandes, L.C.; Figueiredo, B.C.; Soccol, C.R. Immunomodulatory and antitumoral properties of Ganoderma lucidum and Agaricus brasiliensis (Agaricomycetes) medicinal mushrooms. Int. J. Med. Mushrooms 2018, 20, 393-403. [CrossRef]

66. Li, S.; Li, J.; Zhang, J.; Wang, W.; Wang, X.; Jing, H.; Ren, Z.; Gao, Z.; Song, X.; Gong, Z.; et al. The antioxidative, antiaging, and hepatoprotective effects of alkali-extractable polysaccharides by Agaricus bisporus. Evid.-Based Complement. Altern. Med. 2017, 2017, 1-12. [CrossRef]

67. do Rocio Andrade Pires, A.; Ruthes, A.C.; Cadena, S.M.S.C.; Iacomini, M. Cytotoxic effect of a mannogalactoglucan extracted from Agaricus bisporus on HepG2 cells. Carbohydr. Polym. 2017, 170, 33-42. [CrossRef]

68. Li, S.; Liu, H.; Wang, W.; Wang, X.; Zhang, C.; Zhang, J.; Jing, H.; Ren, Z.; Gao, Z.; Song, X.; et al. Antioxidant and anti-aging effects of acidic-extractable polysaccharides by Agaricus bisporus. Int. J. Biol. Macromol. 2018, 106, 1297-1306. [CrossRef]

69. Liu, Y.; Zheng, D.; Su, L.; Wang, Q.; Li, Y. Protective effect of polysaccharide from Agaricus bisporus in Tibet area of China against tetrachloride-induced acute liver injury in mice. Int. J. Biol. Macromol. 2018, 118, 1488-1493. [CrossRef] [PubMed]

70. Zhao, X.; Hou, P.; Xin, H.; Zhang, Y.; Zhou, A.; Lai, C.; Xie, J. A glucogalactomanan polysaccharide isolated from Agaricus bisporus causes an inflammatory response via the ERK/MAPK and IKB/NFKB pathways in macrophages. Int. J. Biol. Macromol. 2020, 151, 1067-1073. [CrossRef] [PubMed]

71. Liu, Z.; Xing, J.; Zheng, S.; Bo, R.; Luo, L.; Huang, Y.; Niu, Y.; Li, Z.; Wang, D.; Hu, Y.; et al. Ganoderma lucidum polysaccharides encapsulated in liposome as an adjuvant to promote Th1-bias immune response. Carbohydr. Polym. 2016, 142. [CrossRef] [PubMed]

72. Jiang, D.; Wang, L.; Zhao, T.; Zhang, Z.; Zhang, R.; Jin, J.; Cai, Y.; Wang, F. Restoration of the tumor-suppressor function to mutant p53 by Ganoderma lucidum polysaccharides in colorectal cancer cells. Oncol. Rep. 2017, 37, 594-600. [CrossRef] [PubMed]

73. Sun, X.; Liao, Y.; Li, W.; Guo, L. Neuroprotective effects of Ganoderma lucidum polysaccharides against oxidative stress-induced neuronal apoptosis. Neural Regen. Res. 2017, 12, 953. [CrossRef]

74. Zhao, X.; Zhou, D.; Liu, Y.; Li, C.; Zhao, X.; Li, Y.; Li, W. Ganoderma lucidum polysaccharide inhibits prostate cancer cell migration via the protein arginine methyltransferase 6 signaling pathway. Mol. Med. Rep. 2017, 17, 147-157. [CrossRef] [PubMed] 
75. Wang, C.; Shi, S.; Chen, Q.; Lin, S.; Wang, R.; Wang, S.; Chen, C. Antitumor and immunomodulatory activities of Ganoderma lucidum polysaccharides in glioma-bearing rats. Integr. Cancer Ther. 2018, 17, 674-683. [CrossRef]

76. Liu, Y.; Li, Y.; Zhang, W.; Sun, M.; Zhang, Z. Hypoglycemic effect of inulin combined with Ganoderma lucidum polysaccharides in T2DM rats. J. Funct. Foods 2019, 55, 381-390. [CrossRef]

77. Xu, Y.; Zhang, X.; Yan, X.-H.; Zhang, J.-L.; Wang, L.-Y.; Xue, H.; Jiang, G.-C.; Ma, X.-T.; Liu, X.-J. Characterization, hypolipidemic and antioxidant activities of degraded polysaccharides from Ganoderma lucidum. Int. J. Biol. Macromol. 2019, 135, 706-716. [CrossRef] [PubMed]

78. Chen, M.; Xiao, D.; Liu, W.; Song, Y.; Zou, B.; Li, L.; Li, P.; Cai, Y.; Liu, D.; Liao, Q.; et al. Intake of Ganoderma lucidum polysaccharides reverses the disturbed gut microbiota and metabolism in type 2 diabetic rats. Int. J. Biol. Macromol. 2020, 155, 890-902. [CrossRef]

79. Zhang, Y.; Sun, D.; Meng, Q.; Guo, W.; Chen, Q.; Zhang, Y. Grifola frondosa polysaccharides induce breast cancer cell apoptosis via the mitochondrial-dependent apoptotic pathway. Int. J. Mol. Med. 2017, 40, 1089-1095. [CrossRef] [PubMed]

80. Chen, Z.; Tang, Y.; Liu, A.; Jin, X.; Zhu, J.; Lu, X. Oral administration of Grifola frondosa polysaccharides improves memory impairment in aged rats via antioxidant action. Mol. Nutr. Food Res. 2017, 61, 1700313. [CrossRef]

81. Chen, Y.; Liu, D.; Wang, D.; Lai, S.; Zhong, R.; Liu, Y.; Yang, C.; Liu, B.; Sarker, M.R.; Zhao, C. Hypoglycemic activity and gut microbiota regulation of a novel polysaccharide from Grifola frondosa in type 2 diabetic mice. Food Chem. Toxicol. 2019, 126, 295-302. [CrossRef]

82. Guo, W.-L.; Deng, J.-C.; Pan, Y.-Y.; Xu, J.-X.; Hong, J.-L.; Shi, F.-F.; Liu, G.-L.; Qian, M.; Bai, W.-D.; Zhang, W.; et al. Hypoglycemic and hypolipidemic activities of Grifola frondosa polysaccharides and their relationships with the modulation of intestinal microflora in diabetic mice induced by high-fat diet and streptozotocin. Int. J. Biol. Macromol. 2020, 153, 1231-1240. [CrossRef]

83. Ren, Z.; Qin, T.; Qiu, F.; Song, Y.; Lin, D.; Ma, Y.; Li, J.; Huang, Y. Immunomodulatory effects of hydroxyethylated Hericium erinaceus polysaccharide on macrophages RAW264.7. Int. J. Biol. Macromol. 2017, 105, 879-885. [CrossRef] [PubMed]

84. Qin, T.; Ren, Z.; Huang, Y.; Song, Y.; Lin, D.; Li, J.; Ma, Y.; Wu, X.; Qiu, F.; Xiao, Q. Selenizing Hericium erinaceus polysaccharides induces dendritic cells maturation through MAPK and NF-kB signaling pathways. Int. J. Biol. Macromol. 2017, 97, 287-298. [CrossRef]

85. Wang, X.-Y.; Yin, J.-Y.; Zhao, M.-M.; Liu, S.-Y.; Nie, S.-P.; Xie, M.-Y. Gastroprotective activity of polysaccharide from Hericium erinaceus against ethanol-induced gastric mucosal lesion and pylorus ligation-induced gastric ulcer, and its antioxidant activities. Carbohydr. Polym. 2018, 186, 100-109. [CrossRef] [PubMed]

86. Liao, B.; Zhou, C.; Liu, T.; Dai, Y.; Huang, H. A novel Hericium erinaceus polysaccharide: Structural characterization and prevention of H2O2-induced oxidative damage in GES-1 cells. Int. J. Biol. Macromol. 2020, 154, 1460-1470. [CrossRef]

87. Liu, J.Y.; Hou, X.X.; Li, Z.Y.; Shan, S.H.; Chang, M.C.; Feng, C.P.; Wei, Y. Isolation and structural characterization of a novel polysaccharide from Hericium erinaceus fruiting bodies and its arrest of cell cycle at S-phage in colon cancer cells. Int. J. Biol. Macromol. 2020, 157, 288-295. [CrossRef] [PubMed]

88. Liu, X.; Ren, Z.; Yu, R.; Chen, S.; Zhang, J.; Xu, Y.; Meng, Z.; Luo, Y.; Zhang, W.; Huang, Y.; et al. Structural characterization of enzymatic modification of Hericium erinaceus polysaccharide and its immune-enhancement activity. Int. J. Biol. Macromol. 2021, 166, 1396-1408. [CrossRef]

89. Du, J.; Wang, R.; Zhang, W.; Zhang, C.; Li, X.; Shi, X.; Hu, M.; Ma, F.; Ma, C.; Wang, X.; et al. A polysaccharide derived from Lentinus edodes impairs the immunosuppressive function of myeloid-derived suppressor cells via the p38 pathways. RSC Adv. 2017, 7, 36533-36540. [CrossRef]

90. Ya, G. A Lentinus edodes polysaccharide induces mitochondrial-mediated apoptosis in human cervical carcinoma HeLa cells. Int. J. Biol. Macromol. 2017, 103, 676-682. [CrossRef]

91. Ren, Z.; Liu, W.; Song, X.; Qi, Y.; Zhang, C.; Gao, Z.; Zhang, J.; Jia, L. Antioxidant and anti-inflammation of enzymatic-hydrolysis residue polysaccharides by Lentinula edodes. Int. J. Biol. Macromol. 2018, 120, 811-822. [CrossRef]

92. Song, X.; Ren, Z.; Wang, X.; Jia, L.; Zhang, C. Antioxidant, anti-inflammatory and renoprotective effects of acidic-hydrolytic polysaccharides by spent mushroom compost (Lentinula edodes) on LPS-induced kidney injury. Int. J. Biol. Macromol. 2020, 151, 1267-1276. [CrossRef]

93. Chen, S.; Liu, C.; Huang, X.; Hu, L.; Huang, Y.; Chen, H.; Fang, Q.; Dong, N.; Li, M.; Tang, W.; et al. Comparison of immunomodulatory effects of three polysaccharide fractions from Lentinula edodes water extracts. J. Funct. Foods 2020, 66, 103791. [CrossRef]

94. Xiang, F.; Lin, L.; Hu, M.; Qi, X. Therapeutic efficacy of a polysaccharide isolated from Cordyceps sinensis on hypertensive rats. Int. J. Biol. Macromol. 2016, 82, 308-314. [CrossRef]

95. Zhengqi, Z.; Qiuli, C.; Yufeng, W.; Hui, Z.; Ying, W.; Hongping, Y.; Long, Y. Protective effects of Cordyceps sinensis polysaccharide CPS-A on angiotensin ll-induced injury of liver L02 cells. J. China Pharm. Univ. 2017, 48, 490-495. [CrossRef]

96. Ying, M.; Yu, Q.; Zheng, B.; Wang, H.; Wang, J.; Chen, S.; Gu, Y.; Nie, S.; Xie, M. Cultured Cordyceps sinensis polysaccharides attenuate cyclophosphamide-induced intestinal barrier injury in mice. J. Funct. Foods 2019, 62, 103523. [CrossRef]

97. Ying, M.; Yu, Q.; Zheng, B.; Wang, H.; Wang, J.; Chen, S.; Nie, S.; Xie, M. Cultured Cordyceps sinensis polysaccharides modulate intestinal mucosal immunity and gut microbiota in cyclophosphamide-treated mice. Carbohydr. Polym. 2020, 235. [CrossRef] [PubMed] 
98. Chen, L.; Zhang, L.; Wang, W.; Qiu, W.; Liu, L.; Ning, A.; Cao, J.; Huang, M.; Zhong, M. Polysaccharides isolated from Cordyceps sinensis contribute to the progression of NASH by modifying the gut microbiota in mice fed a high-fat diet. PLOS ONE 2020, 15, e0232972. [CrossRef] [PubMed]

99. Guan, J.; Han, L.; Shi, N.; Zhu, H.; Wang, J. Development, in vitro biocompatibility, and antitumor efficacy of acetic acid-modified Cordyceps sinensis polysaccharide nanoparticle drug delivery system. Brazilian J. Pharm. Sci. 2020, 56, e18470. [CrossRef]

100. Qi, W.; Zhou, X.; Wang, J.; Zhang, K.; Zhou, Y.; Chen, S.; Nie, S.; Xie, M. Cordyceps sinensis polysaccharide inhibits colon cancer cells growth by inducing apoptosis and autophagy flux blockage via mTOR signaling. Carbohydr. Polym. 2020, 237. [CrossRef] [PubMed]

101. Ren, D.; Wang, N.; Guo, J.; Yuan, L.; Yang, X. Chemical characterization of Pleurotus eryngii polysaccharide and its tumor-inhibitory effects against human hepatoblastoma HepG-2 cells. Carbohydr. Polym. 2016, 138, 123-133. [CrossRef] [PubMed]

102. Chen, L.; Zhang, Y.; Sha, O.; Xu, W.; Wang, S. Hypolipidaemic and hypoglycaemic activities of polysaccharide from Pleurotus eryngii in Kunming mice. Int. J. Biol. Macromol. 2016, 93, 1206-1209. [CrossRef] [PubMed]

103. Xu, D.; Wang, H.; Zheng, W.; Gao, Y.; Wang, M.; Zhang, Y.; Gao, Q. Charaterization and immunomodulatory activities of polysaccharide isolated from Pleurotus eryngii. Int. J. Biol. Macromol. 2016, 92, 30-36. [CrossRef] [PubMed]

104. Zhao, Y.; Chen, X.; Zhao, Y.; Jia, W.; Chang, X.; Liu, H.; Liu, N. Optimization of extraction parameters of Pleurotus eryngii polysaccharides and evaluation of the hypolipidemic effect. RSC Adv. 2020, 10, 11918-11928. [CrossRef]

105. Zhang, C.J.; Guo, J.Y.; Cheng, H.; Lin, L.; Liu, Y.; Shi, Y.; Xu, J.; Yu, H.T. Protective effects of the king oyster culinary-medicinal mushroom, Pleurotus eryngii (Agaricomycetes), Polysaccharides on $\beta$-Amyloid-induced neurotoxicity in PC12 cells and aging rats, in vitro and in vivo studies. Int. J. Med. Mushrooms 2020, 22, 325-333. [CrossRef]

106. Zhang, Y.; Yang, X.; Jin, G.; Yang, X.; Zhang, Y. Polysaccharides from Pleurotus ostreatus alleviate cognitive impairment in a rat model of Alzheimer's disease. Int. J. Biol. Macromol. 2016, 92, 935-941. [CrossRef] [PubMed]

107. Wisbeck, E.; Facchini, J.M.; Alves, E.P.; Silveira, M.L.L.; Gern, R.M.M.; Ninow, J.L.; Furlan, S.A. A polysaccharide fraction extracted from Pleurotus ostreatus mycelial biomass inhibit Sarcoma 180 tumor. An. Acad. Bras. Cienc. 2017, 89, 2013-2020. [CrossRef]

108. Zhang, Y.; Wang, Z.; Jin, G.; Yang, X.; Zhou, H. Regulating dyslipidemia effect of polysaccharides from Pleurotus ostreatus on fat-emulsion-induced hyperlipidemia rats. Int. J. Biol. Macromol. 2017, 101, 107-116. [CrossRef]

109. Uddin Pk, M.M.; Islam, M.S.; Pervin, R.; Dutta, S.; Talukder, R.I.; Rahman, M. Optimization of extraction of antioxidant polysaccharide from Pleurotus ostreatus (Jacq.) P. Kumm and its cytotoxic activity against murine lymphoid cancer cell line. PLoS ONE 2019, 14, e0209371. [CrossRef]

110. Zhang, Y.; Zhang, Z.; Liu, H.; Wang, D.; Wang, J.; Deng, Z.; Li, T.; He, Y.; Yang, Y.; Zhong, S. Physicochemical characterization and antitumor activity in vitro of a selenium polysaccharide from Pleurotus ostreatus. Int. J. Biol. Macromol. 2020, 165, 2934-2946. [CrossRef]

111. Duan, Z.; Zhang, Y.; Zhu, C.; Wu, Y.; Du, B.; Ji, H. Structural characterization of phosphorylated Pleurotus ostreatus polysaccharide and its hepatoprotective effect on carbon tetrachloride-induced liver injury in mice. Int. J. Biol. Macromol. 2020, 162, 533-547. [CrossRef]

112. Jhan, M.-H.; Yeh, C.-H.; Tsai, C.-C.; Kao, C.-T.; Chang, C.-K.; Hsieh, C.-W. Enhancing the antioxidant ability of Trametes versicolor polysaccharopeptides by an enzymatic hydrolysis process. Molecules 2016, 21, 1215. [CrossRef] [PubMed]

113. Roca-Lema, D.; Martinez-Iglesias, O.; de Ana Portela, C.F.; Rodríguez-Blanco, A.; Valladares-Ayerbes, M.; Díaz-Díaz, A.; CasasPais, A.; Prego, C.; Figueroa, A. In vitro anti-proliferative and anti-invasive effect of polysaccharide-rich extracts from Trametes versicolor and Grifola frondosa in colon cancer cells. Int. J. Med. Sci. 2019, 16, 231-240. [CrossRef] [PubMed]

114. Huang, Z.; Zhang, M.; Wang, Y.; Zhang, S.; Jiang, X. Extracellular and intracellular polysaccharide extracts of Trametes versicolor improve lipid profiles via serum regulation of lipid-regulating enzymes in hyperlipidemic mice. Curr. Microbiol. 2020, 77, 3526-3537. [CrossRef] [PubMed]

115. Feng, Y.; Zhang, J.; Wen, C.; Sedem Dzah, C.; Chidimma Juliet, I.; Duan, Y.; Zhang, H. Recent advances in Agaricus bisporus polysaccharides: Extraction, purification, physicochemical characterization and bioactivities. Process Biochem. 2020, 94, 39-50. [CrossRef]

116. Li, S.; Liu, M.; Zhang, C.; Tian, C.; Wang, X.; Song, X.; Jing, H.; Gao, Z.; Ren, Z.; Liu, W.; et al. Purification, in vitro antioxidant and in vivo anti-aging activities of soluble polysaccharides by enzyme-assisted extraction from Agaricus bisporus. Int. J. Biol. Macromol. 2018, 109, 457-466. [CrossRef] [PubMed]

117. Jeong, S.C.; Koyyalamudi, S.R.; Jeong, Y.T.; Song, C.H.; Pang, G. Macrophage immunomodulating and antitumor activities of polysaccharides isolated from Agaricus bisporus white button mushrooms. J. Med. Food 2012, 15, 58-65. [CrossRef]

118. Xu, Z.; Chen, X.; Zhong, Z.; Chen, L.; Wang, Y. Ganoderma lucidum polysaccharides: Immunomodulation and potential anti-tumor activities. Am. J. Chin. Med. 2011, 39, 15-27. [CrossRef]

119. Yang, G.; Yang, L.; Zhuang, Y.; Qian, X.; Shen, Y. Ganoderma lucidum polysaccharide exerts anti-tumor activity via MAPK pathways in HL-60 acute leukemia cells. J. Recept. Signal Transduct. 2016, 36, 6-13. [CrossRef]

120. Wang, Y.; Fan, X.; Wu, X. Ganoderma lucidum polysaccharide (GLP) enhances antitumor immune response by regulating differentiation and inhibition of MDSCs via a CARD9-NF-kB-IDO pathway. Biosci. Rep. 2020, 40. [CrossRef]

121. Huang, S.; Mao, J.; Ding, K.; Zhou, Y.; Zeng, X.; Yang, W.; Wang, P.; Zhao, C.; Yao, J.; Xia, P.; et al. Polysaccharides from Ganoderma lucidum promote cognitive function and neural progenitor proliferation in mouse model of Alzheimer's disease. Stem Cell Rep. 2017, 8, 84-94. [CrossRef] 
122. He, Y.; Zhang, L.; Wang, H. The biological activities of the antitumor drug Grifola frondosa polysaccharide. Prog. Mol. Biol. Transl. Sci. 2019, 163, 221-261. [CrossRef]

123. Mizuno, T.; Wasa, T.; Ito, H.; Suzuki, C.; Ukai, N. Antitumor-active polysaccharides isolated from the fruiting body of Hericium erinaceum, an edible and medicinal mushroom called yamabushitake or houtou. Biosci. Biotechnol. Biochem. 1992, 56, 347-348. [CrossRef] [PubMed]

124. He, X.; Wang, X.; Fang, J.; Chang, Y.; Ning, N.; Guo, H.; Huang, L.; Huang, X.; Zhao, Z. Structures, biological activities, and industrial applications of the polysaccharides from Hericium erinaceus (Lion's Mane) mushroom: A review. Int. J. Biol. Macromol. 2017, 97, 228-237. [CrossRef] [PubMed]

125. Chong, P.S.; Fung, M.-L.; Wong, K.H.; Lim, L.W. Therapeutic potential of Hericium erinaceus for depressive disorder. Int. J. Mol. Sci. 2019, 21, 163. [CrossRef] [PubMed]

126. Ratto, D.; Corana, F.; Mannucci, B.; Priori, E.C.; Cobelli, F.; Roda, E.; Ferrari, B.; Occhinegro, A.; Di Iorio, C.; De Luca, F.; et al. Hericium erinaceus improves recognition memory and induces hippocampal and cerebellar neurogenesis in frail mice during aging. Nutrients 2019, 11, 715. [CrossRef]

127. Wang, J.; Li, W.; Huang, X.; Liu, Y.; Li, Q.; Zheng, Z.; Wang, K. A polysaccharide from Lentinus edodes inhibits human colon cancer cell proliferation and suppresses tumor growth in athymic nude mice. Oncotarget 2017, 8, 610-623. [CrossRef]

128. Zhao, Y.; Chen, X.; Jia, W.; Gong, G.; Zhao, Y.; Li, G.; Zhou, J.; Li, X.; Zhao, Y.; Ma, W. Extraction, isolation, characterisation, antioxidant and anti-fatigue activities of Pleurotus eryngii polysaccharides. Int. J. Food Sci. Technol. 2020, 55, 2492-2508. [CrossRef]

129. Zhang, Y.; Hu, T.; Zhou, H.; Zhang, Y.; Jin, G.; Yang, Y. Antidiabetic effect of polysaccharides from Pleurotus ostreatus in streptozotocin-induced diabetic rats. Int. J. Biol. Macromol. 2016, 83, 126-132. [CrossRef] [PubMed]

130. Dicks, L.; Ellinger, S. Effect of the intake of oyster mushrooms (Pleurotus ostreatus) on cardiometabolic parameters-A systematic review of clinical trials. Nutrients 2020, 12, 1134. [CrossRef]

131. Habtemariam, S. Trametes versicolor (Synn. Coriolus versicolor) polysaccharides in cancer therapy: Targets and efficacy. Biomedicines 2020, 8, 135. [CrossRef]

132. Bulam, S.; Şule Üstün, N.; Pekşen, A. $\beta$-Glucans: An important bioactive molecule of edible and medicinal mushrooms. In Proceedings of the International Technological Sciences and Design Symposium (ITESDES), Giresun, Turkey, 27-29 June 2018; pp. 1242-1258.

133. Mirończuk-Chodakowska, I.; Witkowska, A.M. Evaluation of polish wild mushrooms as beta-glucan sources. Int. J. Environ. Res. Public Health 2020, 17, 7299. [CrossRef] [PubMed]

134. Kataoka, K.; Muta, T.; Yamazaki, S.; Takeshige, K. Activation of macrophages by linear (1 $\rightarrow 3)$ - $\beta$-d-glucans. J. Biol. Chem. 2002, 277, 36825-36831. [CrossRef] [PubMed]

135. Vetvicka, V.; Yvin, J.-C. Effects of marine $\beta-1,3$ glucan on immune reactions. Int. Immunopharmacol. 2004, 4, 721-730. [CrossRef] [PubMed]

136. Mandal, S.; Maity, K.K.; Bhunia, S.K.; Dey, B.; Patra, S.; Sikdar, S.R.; Islam, S.S. Chemical analysis of new water-soluble (1 $\rightarrow 6)-$, $(1 \rightarrow 4)-\alpha, \beta$-glucan and water-insoluble $(1 \rightarrow 3)-,(1 \rightarrow 4)$ - $\beta$-glucan (Calocyban) from alkaline extract of an edible mushroom, Calocybe indica (Dudh Chattu). Carbohydr. Res. 2010, 345, 2657-2663. [CrossRef]

137. Datta, S.; Dubey, J.; Gupta, S.; Paul, A.; Gupta, P.; Mitra, A.K. Tropical milky white mushroom, Calocybe indica (Agaricomycetes): An effective antimicrobial agent working in synergism with standard antibiotics. Int. J. Med. Mushrooms 2020, 22, 335-346. [CrossRef] [PubMed]

138. Ghosh, S.K.; Bera, T.; Pal, S. Antiproliferative, apoptotic, and antimigration property of ethyl acetate extract of Calocybe indica against HeLa and CaSki cell lines of cervical cancer, and its antioxidant and mycochemistry analysis. Middle East J. Cancer 2020, 11, 454-468. [CrossRef]

139. Wang, X.-Y.; Zhang, D.; Yin, J.-Y.; Nie, S.-P.; Xie, M.-Y. Recent developments in Hericium erinaceus polysaccharides: Extraction, purification, structural characteristics and biological activities. Crit. Rev. Food Sci. Nutr. 2019, 59, S96-S115. [CrossRef] [PubMed]

140. Wang, W.; Gou, X.; Xue, H.; Liu, K. Ganoderan (GDN) regulates the growth, motility and apoptosis of non-small cell lung cancer cells through ERK signaling pathway in vitro and in vivo. Onco. Targets. Ther. 2019, 12, 8821-8832. [CrossRef]

141. Zhong, W.-D.; He, H.-C.; Ou, R.-B.; Bi, X.-C.; Dai, Q.-S.; Han, Z.-D.; Liang, Y.-X.; Ye, Y.-K.; Qin, W.-J.; Li, Z.; et al. Protective effect of ganoderan on renal damage in rats with chronic glomerulonephritis. Clin. Investig. Med. 2008, 31, 212. [CrossRef]

142. Hikino, H.; Ishiyama, M.; Suzuki, Y.; Konno, C. Mechanisms of hypoglycemic activity of Ganoderan B: A Glycan of Ganoderma lucidum fruit bodies. Planta Med. 1989, 55, 423-428. [CrossRef]

143. Han, M.D.; Hoon, J.; Lee, J.W.; Back, S.J.; Kim, S.U.; Yoon, K.H. The composition and bioactivities of ganoderan by mycelial fractionation of Ganoderma lucidum IY009. Korean J. Mycol. 1995, 23, 285-297.

144. Mao, C.F.; Hsu, M.C.; Hwang, W.H. Physicochemical characterization of grifolan: Thixotropic properties and complex formation with Congo Red. Carbohydr. Polym. 2007, 68, 502-510. [CrossRef]

145. Takeyama, T.; Suzuki, I.; Ohno, N.; Oikawa, S.; Sato, K.; Ohsawa, M.; Yadomae, T. Host-mediated antitumor effect of grifolan NMF-5N, a polysaccharide obtained from Grifola frondosa. J. Pharmacobiodyn. 1987, 10, 644-651. [CrossRef] [PubMed]

146. Ishibashi, K.; Miura, N.N.; Adachi, Y.; Ohno, N.; Yadomae, T. Relationship between solubility of Grifolan, a Fungal 1,3- $\beta$-Dglucan, and production of tumor necrosis factor by macrophages in vitro. Biosci. Biotechnol. Biochem. 2001, 65, 1993-2000. [CrossRef] [PubMed] 
147. Seo, Y.R.; Patel, D.K.; Shin, W.C.; Sim, W.S.; Lee, O.H.; Lim, K.T. Structural elucidation and immune-enhancing effects of novel polysaccharide from Grifola frondosa. Biomed Res. Int. 2019, 2019, 1-7. [CrossRef]

148. Ulbricht, C.; Weissner, W.; Basch, E.; Giese, N.; Hammerness, P.; Rusie-Seamon, E.; Varghese, M.; Woods, J. Maitake mushroom (Grifola frondosa): Systematic review by the natural standard research collaboration. J. Soc. Integr. Oncol. 2009, 7, 66-72. [CrossRef]

149. Lu, H.; Yang, Y.; Gad, E.; Wenner, C.A.; Chang, A.; Larson, E.R.; Dang, Y.; Martzen, M.; Standish, L.J.; Disis, M.L. Polysaccharide Krestin is a novel TLR2 agonist that mediates inhibition of tumor growth via stimulation of CD8 T cells and NK cells. Clin. Cancer Res. 2011, 17, 67-76. [CrossRef]

150. Nakajima, T.; Ichikawa, S.; Uchida, S.; Komada, T. Effects of a protein-bound polysaccharide from a basidiomycetes against hepatocarcinogenesis induced by 3'-methyl-4-dimethylaminoazobenzene in rats. Clin. Ther. 1990, 12, $385-392$.

151. Hirose, K.; Hakozaki, M.; Matsunaga, K.; Yoshikumi, C.; Hotta, T.; Yanagisawa, M.; Yamamoto, M.; Endo, H. Cloning of sequences induced and suppressed by administration of PSK, antitumor protein-bound polysaccharide. Biochem. Biophys. Res. Commun. 1985, 126, 884-892. [CrossRef]

152. Sullivan, R.; Smith, J.E.; Rowan, N.J. Medicinal mushrooms and cancer therapy: Translating a traditional practice into western medicine. Perspect. Biol. Med. 2006, 49, 159-170. [CrossRef] [PubMed]

153. Ito, H.; Hidaka, H.; Sugiura, M. Effects of coriolan, an antitumor polysaccharide, produced by Coriolus versicolor Iwade. Jpn. J. Pharmacol. 1979, 29, 953-957. [CrossRef]

154. Zhang, Y.; Li, S.; Wang, X.; Zhang, L.; Cheung, P.C.K. Advances in lentinan: Isolation, structure, chain conformation and bioactivities. Food Hydrocoll. 2011, 25, 196-206. [CrossRef]

155. Liu, Y.; Sun, B.; Zhu, G.; Li, W.; Tian, Y.; Wang, L.; Zong, S.; Sheng, P.; Li, M.; Chen, S.; et al. Selenium-lentinan inhibits tumor progression by regulating epithelial-mesenchymal transition. Toxicol. Appl. Pharmacol. 2018, 360, 1-8. [CrossRef] [PubMed]

156. Zi, Y.; Jiang, B.; He, C.; Liu, L. Lentinan inhibits oxidative stress and inflammatory cytokine production induced by benzo(a)pyrene in human keratinocytes. J. Cosmet. Dermatol. 2020, 19, 502-507. [CrossRef]

157. Zhang, M.; Zhang, Y.; Zhang, L.; Tian, Q. Mushroom polysaccharide lentinan for treating different types of cancers: A review of 12 years clinical studies in China. Prog. Mol. Biol. Transl. Sci. 2019, 163, 297-328. [CrossRef]

158. Zhang, Y.; Zhang, M.; Jiang, Y.; Li, X.; He, Y.; Zeng, P.; Guo, Z.; Chang, Y.; Luo, H.; Liu, Y.; et al. Lentinan as an immunotherapeutic for treating lung cancer: A review of 12 years clinical studies in China. J. Cancer Res. Clin. Oncol. 2018, 144, 2177-2186. [CrossRef]

159. Murphy, E.J.; Masterson, C.; Rezoagli, E.; O’Toole, D.; Major, I.; Stack, G.D.; Lynch, M.; Laffey, J.G.; Rowan, N.J. $\beta$-Glucan extracts from the same edible shiitake mushroom Lentinus edodes produce differential in-vitro immunomodulatory and pulmonary cytoprotective effects-Implications for coronavirus disease (COVID-19) immunotherapies. Sci. Total Environ. 2020, 732, 139330. [CrossRef]

160. Parola, S.; Chiodaroli, L.; Orlandi, V.; Vannin, C.; Panno, L. Lentinula edodes and Pleurotus ostreatus: Functional food with antioxidant-Antimicrobial activity and an important source of Vitamin D and medicinal compounds. Funct. Foods Health Dis. 2017, 7, 773. [CrossRef]

161. Yang, D.; Zhou, Z.; Zhang, L. An overview of fungal glycan-based therapeutics. In Progress in Molecular Biology and Translational Science; Elsevier: Amsterdam, The Netherlands, 2019; Volume 163, pp. 135-163.

162. Fujimoto, K.; Tomonaga, M.; Goto, S. A case of recurrent ovarian cancer successfully treated with adoptive immunotherapy and lentinan. Anticancer Res. 2006, 26, 4015-4018. [PubMed]

163. Wang, Y.; Jin, H.; Yu, J.; Qu, C.; Wang, Q.; Yang, S.; Ma, S.; Ni, J. Quality control and immunological activity of lentinan samples produced in China. Int. J. Biol. Macromol. 2020, 159, 129-136. [CrossRef]

164. Wasser, S.P.; Weis, A.L. Medicinal properties of substances occurring in higher basidiomycetes mushrooms: Current perspectives (review). Int. J. Med. Mushrooms 1999, 1, 31-62. [CrossRef]

165. Chen, Q.; Peng, H.; Dong, L.; Chen, L.; Ma, X.; Peng, Y.; Dai, S.; Liu, Q. Activation of the NRF2-ARE signalling pathway by the Lentinula edodes polysaccharose LNT alleviates ROS-mediated cisplatin nephrotoxicity. Int. Immunopharmacol. 2016, 36, 1-8. [CrossRef]

166. Markova, N.; Michailova, L.; Kussovski, V.; Jourdanova, M.; Radoucheva, T. Intranasal application of lentinan enhances bactericidal activity of rat alveolar macrophages against Mycobacterium tuberculosis. Pharmazie 2005, 60, 42-48.

167. Kupfahl, C.; Geginat, G.; Hof, H. Lentinan has a stimulatory effect on innate and adaptive immunity against murine Listeria monocytogenes infection. Int. Immunopharmacol. 2006, 6, 686-696. [CrossRef] [PubMed]

168. Drandarska, I.; Kussovski, V.; Nikolaeva, S.; Markova, N. Combined immunomodulating effects of BCG and Lentinan after intranasal application in guinea pigs. Int. Immunopharmacol. 2005, 5, 795-803. [CrossRef]

169. Guo, Z.; Hu, Y.; Wang, D.; Ma, X.; Zhao, X.; Zhao, B.; Wang, J.; Liu, P. Sulfated modification can enhance the adjuvanticity of lentinan and improve the immune effect of ND vaccine. Vaccine 2009, 27, 660-665. [CrossRef]

170. Zhou, L.; Zhang, Q.; Zhang, Y.; Liu, J.; Cao, Y. The shiitake mushroom-derived immuno-stimulant lentinan protects against murine malaria blood-stage infection by evoking adaptive immune-responses. Int. Immunopharmacol. 2009, 9, 455-462. [CrossRef]

171. Gordon, M.; Guralnik, M.; Kaneko, Y.; Mimura, T.; Goodgame, J.; DeMarzo, C.; Pierce, D.; Baker, M.; Lang, W. A phase II controlled study of a combination of the immune modulator, lentinan, with didanosine (DDI) in HIV patients with CD4 cells of 200-500/MM3. J. Med. 1995, 26, 193-207.

172. Gordon, M.; Bihari, B.; Goosby, E.; Gorter, R.; Greco, M.; Guralnik, M.; Mimura, T.; Rudinicki, V.; Wong, R.; Kaneko, Y. A placebo-controlled trial of the immune modulator, lentinan, in HIV- positive patients: A phase I/II trial. J. Med. 1998, 29, 305-330. 
173. Bergendiova, K.; Tibenska, E.; Majtan, J. Pleuran ( $\beta$-glucan from Pleurotus ostreatus) supplementation, cellular immune response and respiratory tract infections in athletes. Eur. J. Appl. Physiol. 2011, 111, 2033-2040. [CrossRef]

174. Jesenak, M.; Majtan, J.; Rennerova, Z.; Kyselovic, J.; Banovcin, P.; Hrubisko, M. Immunomodulatory effect of pleuran ( $\beta$-glucan from Pleurotus ostreatus) in children with recurrent respiratory tract infections. Int. Immunopharmacol. 2013, 15, 395-399. [CrossRef]

175. Pasnik, J.; Ślemp, A.; Cywinska-Bernas, A.; Zeman, K.; Jesenak, M. Preventive effect of pleuran ( $\beta$-glucan from Pleurotus ostreatus) in children with recurrent respiratory tract infections-Open-label prospective study. Curr. Pediatr. Res. 2017, 21, 99-104.

176. Urbancikova, I.; Hudackova, D.; Majtan, J.; Rennerova, Z.; Banovcin, P.; Jesenak, M. Efficacy of pleuran ( $\beta$-glucan from Pleurotus ostreatus) in the management of Herpes simplex virus type 1 infection. Evid. Based Complement. Altern. Med. 2020, 2020, 1-8. [CrossRef]

177. Zhang, Y.; Kong, H.; Fang, Y.; Nishinari, K.; Phillips, G.O. Schizophyllan: A review on its structure, properties, bioactivities and recent developments. Bioact. Carbohydrates Diet. Fibre 2013, 1, 53-71. [CrossRef]

178. Sung, K.H.; Josewski, J.; Dübel, S.; Blankenfeldt, W.; Rau, U. Structural insights into antigen recognition of an anti- $\beta-(1,6)-\beta-(1,3)-$ D-glucan antibody. Sci. Rep. 2018, 8, 13652. [CrossRef]

179. Leathers, T.D.; Nunnally, M.S.; Price, N.P. Co-production of schizophyllan and arabinoxylan from corn fiber. Biotechnol. Lett. 2006, 28, 623-626. [CrossRef]

180. Scarpari, M.; Reverberi, M.; Parroni, A.; Scala, V.; Fanelli, C.; Pietricola, C.; Zjalic, S.; Maresca, V.; Tafuri, A.; Ricciardi, M.R.; et al. Tramesan, a novel polysaccharide from Trametes versicolor. Structural characterization and biological effects. PLoS ONE 2017, 12, e0171412. [CrossRef]

181. Lakhanpal, T.N.; Rana, M. Medicinal and nutraceutical genetic resources of mushrooms. Plant Genet. Resour. 2005, 3, 288-303. [CrossRef]

182. Ricciardi, M.R.; Licchetta, R.; Mirabilii, S.; Scarpari, M.; Parroni, A.; Fabbri, A.A.; Cescutti, P.; Reverberi, M.; Fanelli, C.; Tafuri, A. Preclinical antileukemia activity of Tramesan: A newly identified bioactive fungal metabolite. Oxid. Med. Cell. Longev. 2017, 2017, 1-8. [CrossRef]

183. Loncar, J.; Bellich, B.; Parroni, A.; Reverberi, M.; Rizzo, R.; Zjalić, S.; Cescutti, P. Oligosaccharides derived from Tramesan: Their structure and activity on mycotoxin inhibition in Aspergillus flavus and Aspergillus carbonarius. Biomolecules 2021, 11, 243. [CrossRef]

184. Scala, V.; Pietricola, C.; Farina, V.; Beccaccioli, M.; Zjalic, S.; Quaranta, F.; Fornara, M.; Zaccaria, M.; Momeni, B.; Reverberi, M.; et al. Tramesan elicits durum wheat defense against the Septoria disease complex. Biomolecules 2020, 10, 608. [CrossRef]

185. Xu, X.; Yan, H.; Chen, J.; Zhang, X. Bioactive proteins from mushrooms. Biotechnol. Adv. 2011, 29, 667-674. [CrossRef] [PubMed]

186. Kumar, K.; Reddy, G.; Reddy, B.; Shekar, P.; Sumanthi, J.; Chandra, K.P. Biological role of lectins: A review. J. Orofac. Sci. 2012, 4, 20. [CrossRef]

187. Liu, Q.; Ng, T.; Wang, H. Isolation and characterization of a novel lectin from the wild mushroom Oudemansiella radicata (Relhan.: Fr.) sing. Biotechnol. Bioprocess Eng. 2013, 18, 465-471. [CrossRef]

188. Lam, S.K.; Ng, T.B. Lectins: Production and practical applications. Appl. Microbiol. Biotechnol. 2011, 89, 45-55. [CrossRef] [PubMed]

189. Kumaran, S.; Pandurangan, A.K.; Shenbhagaraman, R.; Esa, N.M. Isolation and characterization of lectin from the artist's conk medicinal mushroom, Ganoderma applanatum (Agaricomycetes), and evaluation of its antiproliferative activity in HT-29 colon cancer cells. Int. J. Med. Mushrooms 2017, 19, 675-684. [CrossRef] [PubMed]

190. Ditamo, Y.; Rupil, L.L.; Sendra, V.G.; Nores, G.A.; Roth, G.A.; Irazoqui, F.J. In vivo immunomodulatory effect of the lectin from edible mushroom Agaricus bisporus. Food Funct. 2016, 7, 262-269. [CrossRef]

191. He, M.; Su, D.; Liu, Q.; Gao, W.; Kang, Y. Mushroom lectin overcomes hepatitis B virus tolerance via TLR6 signaling. Sci. Rep. 2017, 7, 5814. [CrossRef]

192. Kawagishi, H.; Suzuki, H.; Watanabe, H.; Nakamura, H.; Sekiguchi, T.; Murata, T.; Usui, T.; Sugiyama, K.; Suganuma, H.; Inakuma, T.; et al. A lectin from an edible mushroom Pleurotus ostreatus as a food intake-suppressing substance. Biochim. Biophys. Acta Gen. Subj. 2000, 1474, 299-308. [CrossRef]

193. Ismaya, W.T. In silico study to develop a lectin-like protein from mushroom Agaricus bisporus for pharmaceutical application. Sci. Pharm. 2016, 84, 203-217. [CrossRef] [PubMed]

194. Weigand-Heller, A.J.; Kris-Etherton, P.M.; Beelman, R.B. The bioavailability of ergothioneine from mushrooms (Agaricus bisporus) and the acute effects on antioxidant capacity and biomarkers of inflammation. Prev. Med. 2012, 54, S75-S78. [CrossRef]

195. Liu, X.; Huang, Y.; Wang, J.; Zhou, S.; Wang, Y.; Cai, M.; Yu, L.; Tang, Q. A study on the antioxidant properties and stability of ergothioneine from culinary-medicinal mushrooms. Int. J. Med. Mushrooms 2020, 22, 211-220. [CrossRef] [PubMed]

196. Borodina, I.; Kenny, L.C.; McCarthy, C.M.; Paramasivan, K.; Pretorius, E.; Roberts, T.J.; van der Hoek, S.A.; Kell, D.B. The biology of ergothioneine, an antioxidant nutraceutical. Nutr. Res. Rev. 2020, 33, 190-217. [CrossRef]

197. Halliwell, B.; Cheah, I.K.; Tang, R.M.Y. Ergothioneine-A diet-derived antioxidant with therapeutic potential. FEBS Lett. 2018, 592, 3357-3366. [CrossRef] [PubMed]

198. Cheah, I.K.; Halliwell, B. Could ergothioneine aid in the treatment of coronavirus patients? Antioxidants $2020,9,595$. [CrossRef] [PubMed]

199. Wang, H.X.; Ng, T.B. Flammulin: A novel ribosome-inactivating protein from fruiting bodies of the winter mushroom Flammulina velutipes. Biochem. Cell Biol. 2000, 78, 699-702. [CrossRef] [PubMed] 
200. Gong, F.; Chen, Y.; Gong, M.; Zhang, C. Crystallization and some characterization of flammulin purified from the fruit bodies of Flammulina velutipes. Bioresour. Technol. 1998, 64, 153-156. [CrossRef]

201. Watanabe, Y.; Nakanishi, K.; Komatsu, N.; Sakabe, T.; Terakawa, H. Flammulin, an antitumor substance. Bull. Chem. Soc. Jpn. 1964, 37, 747-750. [CrossRef]

202. Komatsu, N.; Terakawa, H.; Nakanishi, K.; Watanabe, Y. Flammulin, a basic protein of Flammulina velutipes with antitumor activities. J. Antibiot. 1963, 16. [CrossRef]

203. Ng, T.B.; Ngai, P.H.K.; Xia, L. An agglutinin with mitogenic and antiproliferative activities from the mushroom Flammulina velutipes. Mycologia 2006, 98, 167-171. [CrossRef] [PubMed]

204. Heleno, S.A.; Martins, A.; Queiroz, M.J.R.P.; Ferreira, I.C.F.R. Bioactivity of phenolic acids: Metabolites versus parent compounds: A review. Food Chem. 2015, 173, 501-513. [CrossRef]

205. Ferreira, I.; Barros, L.; Abreu, R. Antioxidants in wild mushrooms. Curr. Med. Chem. 2009, 16, 1543-1560. [CrossRef]

206. Nallathamby, N.; Malek, S.N.A.; Vidyadaran, S.; Phan, C.-W.; Sabaratnam, V. Lipids in an ethyl acetate fraction of caterpillar medicinal mushroom, Cordyceps militaris (Ascomycetes), reduce nitric oxide production in BV2 cells via NRF2 and NF- $\mathrm{B}$ pathways. Int. J. Med. Mushrooms 2020, 22, 1215-1223. [CrossRef]

207. Phan, C.W.; Wong, W.L.; David, P.; Naidu, M.; Sabaratnam, V. Pleurotus giganteus (Berk.) Karunarathna \& K.D. Hyde: Nutritional value and in vitro neurite outgrowth activity in rat pheochromocytoma cells. BMC Complement. Altern. Med. 2012, 12. [CrossRef]

208. Phan, C.W.; Lee, G.S.; Macreadie, I.G.; Malek, S.N.A.; Pamela, D.; Sabaratnam, V. Lipid constituents of the edible mushroom, Pleurotus giganteus demonstrate anti-Candida activity. Nat. Prod. Commun. 2013, 8, 1763-1765. [CrossRef] [PubMed]

209. Barreira, J.C.M.; Oliveira, M.B.P.P.; Ferreira, I.C.F.R. Development of a novel methodology for the analysis of ergosterol in mushrooms. Food Anal. Methods 2014, 7, 217-223. [CrossRef]

210. Kalač, P. A review of chemical composition and nutritional value of wild-growing and cultivated mushrooms. J. Sci. Food Agric. 2013, 93, 209-218. [CrossRef] [PubMed]

211. Dufourc, E.J. Sterols and membrane dynamics. J. Chem. Biol. 2008, 1, 63-77. [CrossRef] [PubMed]

212. Jamzivar, F.; Shams-Ghahfarokhi, M.; Khoramizadeh, M.; Yousefi, N.; Gholami-Shabani, M. Unraveling the importance of molecules of natural origin in antifungal drug development through targeting ergosterol biosynthesis pathway. Iran. J. Microbiol. 2020, 11, 448-459. [CrossRef]

213. Bekiaris, G.; Tagkouli, D.; Koutrotsios, G.; Kalogeropoulos, N.; Zervakis, G.I. Pleurotus mushrooms content in glucans and ergosterol assessed by ATR-FTIR spectroscopy and multivariate analysis. Foods 2020, 9, 535. [CrossRef]

214. Jasinghe, V.J.; Perera, C.O.; Sablani, S.S. Kinetics of the conversion of ergosterol in edible mushrooms. J. Food Eng. 2007, 79, 864-869. [CrossRef]

215. Diallo, I.; Morel, S.; Vitou, M.; Michel, A.; Rapior, S.; Traoré, L.; Poucheret, P.; Fons, F. Ergosterol and amino acids contents of culinary-medicinal Shiitake from various culture conditions. Proceedings 2020, 70, 78. [CrossRef]

216. Shimizu, T.; Kawai, J.; Ouchi, K.; Kikuchi, H.; Osima, Y.; Hidemi, R. Agarol, an ergosterol derivative from Agaricus blazei, induces caspase-independent apoptosis in human cancer cells. Int. J. Oncol. 2016, 48, 1670-1678. [CrossRef] [PubMed]

217. Mattila, P.; Könkö, K.; Eurola, M.; Pihlava, J.-M.; Astola, J.; Vahteristo, L.; Hietaniemi, V.; Kumpulainen, J.; Valtonen, M.; Piironen, V. Contents of vitamins, mineral elements, and some phenolic compounds in cultivated mushrooms. J. Agric. Food Chem. 2001, 49, 2343-2348. [CrossRef]

218. Bernas, E.; Jaworska, G.; Lisiewska, Z. Edible mushrooms as a source of valuable nutritive constituents. Acta Sci. Pol. Technol. Aliment. 2006, 5, 5-20.

219. Pogoń, K.; Gabor, A.; Jaworska, G.; Bernaś, E. Effect of traditional canning in acetic brine on the antioxidants and vitamins in Boletus edulis and Suillus luteus mushrooms. J. Food Process. Preserv. 2017, 41, e12826. [CrossRef]

220. Phillips, K.M.; Horst, R.L.; Koszewski, N.J.; Simon, R.R. Vitamin D4 in mushrooms. PLoS ONE 2012, 7, e40702. [CrossRef]

221. Cardwell, G.; Bornman, J.; James, A.; Black, L. A review of mushrooms as a potential source of dietary Vitamin D. Nutrients 2018, 10, 1498. [CrossRef] [PubMed]

222. Dankers, W.; Colin, E.M.; van Hamburg, J.P.; Lubberts, E. Vitamin D in autoimmunity: Molecular mechanisms and therapeutic potential. Front. Immunol. 2017, 7, 697. [CrossRef] [PubMed]

223. Peleg, S. Molecular basis for differential action of vitamin D analogs. In Vitamin D; Academic Press: Burlington, VT, USA, 2005; Volume 2, pp. 1471-1488.

224. El-Sharkawy, A.; Malki, A. Vitamin D signaling in inflammation and cancer: Molecular mechanisms and therapeutic implications. Molecules 2020, 25, 3219. [CrossRef]

225. Roupas, P.; Keogh, J.; Noakes, M.; Margetts, C.; Taylor, P. Mushrooms and agaritine: A mini-review. J. Funct. Foods 2010, 2, 91-98. [CrossRef]

226. Hashida, C.; Hayashi, K.; Jie, L.; Haga, S.; Sakurai, M.; Shimizu, H. Quantities of agaritine in mushrooms (Agaricus bisporus) and the carcinogenicity of mushroom methanol extracts on the mouse bladder epithelium. [Nippon kōshū eisei zasshi] Jpn. J. Public Health 1990, 37, 400-405.

227. Gao, W.N.; Wei, D.Q.; Li, Y.; Gao, H.; Xu, W.R.; Li, A.X.; Chou, K.C. Agaritine and its derivatives are potential inhibitors against HIV proteases. Med. Chem. 2007, 3, 221-226. [CrossRef] [PubMed]

228. Ali, M.M.; Baig, M.T.; Jabeen, A.; Aslam, M.; Shahid, U. Therapeutic value of medicinal mushroom Agaricus blazei Murill. Pak. J. Med. Dent. 2021, 10, 83-89. [CrossRef] 
229. Ashraf, S.A.; Elkhalifa, A.E.O.; Siddiqui, A.J.; Patel, M.; Awadelkareem, A.M.; Snoussi, M.; Ashraf, M.S.; Adnan, M.; Hadi, S. Cordycepin for health and wellbeing: A potent bioactive metabolite of an entomopathogenic medicinal fungus Cordyceps with its nutraceutical and therapeutic potential. Molecules 2020, 25, 2735. [CrossRef] [PubMed]

230. Tan, L.; Song, X.; Ren, Y.; Wang, M.; Guo, C.; Guo, D.; Gu, Y.; Li, Y.; Cao, Z.; Deng, Y. Anti-inflammatory effects of cordycepin: A review. Phyther. Res. 2021, 35, 1284-1297. [CrossRef]

231. Qin, P.; Li, X.; Yang, H.; Wang, Z.-Y.; Lu, D. Therapeutic potential and biological applications of cordycepin and metabolic mechanisms in cordycepin-producing fungi. Molecules 2019, 24, 2231. [CrossRef]

232. Jin, Y.; Meng, X.; Qiu, Z.; Su, Y.; Yu, P.; Qu, P. Anti-tumor and anti-metastatic roles of cordycepin, one bioactive compound of Cordyceps militaris. Saudi J. Biol. Sci. 2018, 25, 991-995. [CrossRef]

233. Yoon, S.; Park, S.; Park, Y. The anticancer properties of cordycepin and their underlying mechanisms. Int. J. Mol. Sci. 2018, 19, 3027. [CrossRef]

234. An, Y.; Li, Y.; Wang, X.; Chen, Z.; Xu, H.; Wu, L.; Li, S.; Wang, C.; Luan, W.; Wang, X.; et al. Cordycepin reduces weight through regulating gut microbiota in high-fat diet-induced obese rats. Lipids Health Dis. 2018, 17, 276. [CrossRef] [PubMed]

235. Lee, D.; Lee, W.; Jung, K.; Kwon, Y.; Kim, D.; Hwang, G.; Kim, C.; Lee, S.; Kang, K.S. The inhibitory effect of cordycepin on the proliferation of MCF-7 breast cancer cells, and its mechanism: An investigation using network pharmacology-based analysis. Biomolecules 2019, 9, 407. [CrossRef]

236. Kawagishi, H.; Shimada, A.; Shirai, R.; Okamoto, K.; Ojima, F.; Sakamoto, H.; Ishiguro, Y.; Furukawa, S. Erinacines A, B and C, strong stimulators of nerve growth factor (NGF)-synthesis, from the mycelia of Hericium erinaceum. Tetrahedron Lett. 1994, 35, 1569-1572. [CrossRef]

237. Corana, F.; Cesaroni, V.; Mannucci, B.; Baiguera, R.M.; Picco, A.M.; Savino, E.; Ratto, D.; Perini, C.; Kawagishi, H.; Girometta, C.E.; et al. Array of metabolites in Italian Hericium erinaceus mycelium, primordium, and sporophore. Molecules 2019, $24,3511$. [CrossRef] [PubMed]

238. Ma, B.J.; Shen, J.W.; Yu, H.Y.; Ruan, Y.; Wu, T.T.; Zhao, X. Hericenones and erinacines: Stimulators of nerve growth factor (NGF) biosynthesis in Hericium erinaceus. Mycology 2010, 1, 92-98. [CrossRef]

239. Chiu, C.H.; Chyau, C.C.; Chen, C.C.; Lee, L.Y.; Chen, W.P.; Liu, J.L.; Lin, W.H.; Mong, M.C. Erinacine A-enriched Hericium erinaceus mycelium produces antidepressant-like effects through modulating BDNF/PI3K/Akt/GSK-3 $\beta$ signaling in mice. Int. J. Mol. Sci. 2018, 19, 341. [CrossRef]

240. Lu, C.C.; Huang, W.S.; Lee, K.F.; Lee, K.C.; Hsieh, M.C.; Huang, C.Y.; Lee, L.Y.; Lee, B.O.; Teng, C.C.; Shen, C.H.; et al. Inhibitory effect of Erinacines A on the growth of DLD-1 colorectal cancer cells is induced by generation of reactive oxygen species and activation of p70S6K and p21. J. Funct. Foods 2016, 21, 474-484. [CrossRef]

241. Li, I.C.; Chang, H.H.; Lin, C.H.; Chen, W.P.; Lu, T.H.; Lee, L.Y.; Chen, Y.W.; Chen, Y.P.; Chen, C.C.; Lin, D.P.C. Prevention of early Alzheimer's disease by erinacine A-enriched Hericium erinaceus mycelia pilot double-blind placebo-controlled study. Front. Aging Neurosci. 2020, 12, 155. [CrossRef]

242. Liang, C.; Tian, D.; Liu, Y.; Li, H.; Zhu, J.; Li, M.; Xin, M.; Xia, J. Review of the molecular mechanisms of Ganoderma lucidum triterpenoids: Ganoderic acids A, C2, D, F, DM, X and Y. Eur. J. Med. Chem. 2019, 174, 130-141. [CrossRef]

243. Ren, L. Protective effect of ganoderic acid against the streptozotocin induced diabetes, inflammation, hyperlipidemia and microbiota imbalance in diabetic rats. Saudi J. Biol. Sci. 2019, 26, 1961-1972. [CrossRef]

244. Gill, B.S.; Navgeet; Kumar, S. Antioxidant potential of ganoderic acid in Notch-1 protein in neuroblastoma. Mol. Cell. Biochem. 2019, 456. [CrossRef]

245. Hiraki, E.; Furuta, S.; Kuwahara, R.; Takemoto, N.; Nagata, T.; Akasaka, T.; Shirouchi, B.; Sato, M.; Ohnuki, K.; Shimizu, K. Anti-obesity activity of Yamabushitake (Hericium erinaceus) powder in ovariectomized mice, and its potentially active compounds. J. Nat. Med. 2017, 71, 482-491. [CrossRef]

246. Mori, K.; Kikuchi, H.; Obara, Y.; Iwashita, M.; Azumi, Y.; Kinugasa, S.; Inatomi, S.; Oshima, Y.; Nakahata, N. Inhibitory effect of hericenone B from Hericium erinaceus on collagen-induced platelet aggregation. Phytomedicine 2010, 17, 1082-1085. [CrossRef]

247. Boruta, T.; Bizukojc, M. Production of lovastatin and itaconic acid by Aspergillus terreus: A comparative perspective. World J. Microbiol. Biotechnol. 2017, 33, 34. [CrossRef]

248. Kała, K.; Kryczyk-Poprawa, A.; Rzewińska, A.; Muszyńska, B. Fruiting bodies of selected edible mushrooms as a potential source of lovastatin. Eur. Food Res. Technol. 2020, 246, 713-722. [CrossRef]

249. Huang, S.; Chyuan, I.; Shiue, C.; Yu, M.; Hsu, Y.; Hsu, M. Lovastatin-mediated MCF-7 cancer cell death involves LKB1-AMPKp38MAPK-p53-survivin signalling cascade. J. Cell. Mol. Med. 2020, 24, 1822-1836. [CrossRef]

250. Bardeleben, R.; Dunkern, T.; Kaina, B.; Fritz, G. The HMG-CoA reductase inhibitor lovastatin protects cells from the antineoplastic drugs doxorubicin and etoposide. Int. J. Mol. Med. 2002, 10, 473-479. [CrossRef] [PubMed]

251. Zambón, D.; Ros, E.; Rodriguez-Villar, C.; Laguna, J.C.; Vázquez, M.; Sanllehy, C.; Casals, E.; Sol, J.M.; Hernández, G. Randomized crossover study of gemfibrozil versus lovastatin in familial combined hyperlipidemia: Additive effects of combination treatment on lipid regulation. Metabolism 1999, 48, 47-54. [CrossRef]

252. Ali, M.E.; Nizar, N.N.A. Preparation and Processing of Religious and Cultural Foods; Elsevier: Amsterdam, The Netherlands, 2018; ISBN 9780081018927.

253. PMMI Business Intelligence 2019 Nutraceuticals Market Assessment. Available online: https://www.pmmi.org/report/2019 -nutraceuticals-market-assessment (accessed on 10 March 2021). 
254. Chrzan, J. The Global Market for Nutraceuticals Set for Robust Growth. Available online: https://www.healthcarepackaging.com/ markets/neutraceuticals-functional/article/13296428/the-global-market-for-nutraceuticals-set-for-robust-growth (accessed on 16 March 2021).

255. Datam Intelligence Edible Mushrooms Market, Size, Share, Opportunities and Forecast, 2020-2027. Available online: https: / / www.datamintelligence.com/research-report/edible-mushrooms-market (accessed on 18 March 2021).

256. Market Data Forecast Asia Pacific Edible Mushroom Market. Available online: https://www.marketdataforecast.com/marketreports/apac-edible-mushroom-market (accessed on 18 March 2021).

257. Markets and Markets Dietary Supplements Market. Available online: https:/ / www.marketsandmarkets.com/Market-Reports / dietary-supplements-market-973.html (accessed on 18 March 2021).

258. Badalyan, S.M. Potential of mushroom bioactive molecules to develop healthcare biotech products. In Proceedings of the 8th International Conference on Mushroom Biology and Mushroom Products, New Delhi, India, 19-22 November 2014; pp. 373-378.

259. Venkatachalam, G.; Arumugam, S.; Doble, M. Industrial production and applications of $\alpha / \beta$ linear and branched glucans. Indian Chem. Eng. 2020,1-15. [CrossRef]

260. Coherent Market Insights Cordyceps sinensis and militaris Extract Market Analysis. Available online: https://www. coherentmarketinsights.com/market-insight/cordyceps-sinensis-and-militaris-extract-market-2578 (accessed on 18 March 2021).

261. Market Watch Global Lentinan Market 2021 Analysis with Key Players, Applications, Trends and Forecasts by 2027. Available online: https: / / www.marketwatch.com/press-release/global-lentinan-market-2021-analysis-with-key-players-applicationstrends-and-forecasts-by-2027-2021-03-09 (accessed on 18 March 2021).

262. Research and Markets Statin Market: Global Industry Trends, Share, Size, Growth, Opportunity and Forecast 2020-2025. Available online: https:/ / www.researchandmarkets.com/reports/5009067/statin-market-global-industry-trends-share?utm_source= dynamic\&utm_medium=BW\&utm_code=bmkdw4\&utm_campaign=1375328+-+Statin+Market+Insights+and+Trends $\% 2 C+20$ 20-2025\%3A+Atorvastatin\%2C+Fluvastatin\%2C+Lovastat (accessed on 20 March 2021).

263. Globe Newswire the Global Functional Food Market is Forecasted to Reach USD 34.3 Billion by 2024, Growing at a CAGR of 8.04\% during the Forecast Period (2019 2024). Available online: http:/ /www.globenewswire.com/news-release/2020/01/13/196 9374/0/en/The-global-functional-food-market-is-forecasted-to-reach-USD-34-3-billion-by-2024-growing-at-a-CAGR-of-804-during-the-forecast-period-2019.html (accessed on 16 March 2021).

264. Persistence Market Research Medicinal Mushrooms Market: Global Industry Trend Analysis 2013 to 2017 and Forecast $2018-2028$. Available online: https:/ / www.persistencemarketresearch.com/market-research/medicinal-mushrooms-market.asp (accessed on 10 March 2021). 